\title{
ARTICLE \\ Considerations on the Construction of Future Financial Regulations in the Field of Initial Coin Offering
}

\author{
Paweł Szwajdler ${ }^{1}$ iD
}

Accepted: 11 October 2021 / Published online: 4 November 2021

(c) The Author(s) 2021

\begin{abstract}
Legal issues of ICOs are significant in the contemporary financial world because this method of capital formation is becoming widespread. In spite of the significance of ICOs, there are no financial regulations in this field in the most important legal systems. Therefore, research concerning future legal provisions in the area of ICOs is needed. This paper concerns issues related to the scope and structure of future financial regulations applicable to ICOs. The author focuses on principles on which legal provisions in the field of ICOs should be based. National, European and international matters are discussed separately in this work. Matters regarding a future international organisation competent in issues of crypto-assets are elaborated. Furthermore, the author proposes to create a model convention on cryptocurrencies and bilateral agreements on the exchange of information in crypto-asset matters. Disclosure obligations, anti-manipulation provisions and anti-money laundering principles are also set out. Moreover, the author discusses issues regarding audit requirements, special methods of registration and innovative payment rules for crypto-asset purposes. Finally, recommendations concerning ICOs are made separately for national, European and international purposes. The author believes that the conclusions in this paper can be useful not only for legislators but also for international actors, European institutions and legal researchers.
\end{abstract}

Keywords Initial Coin Offering · Cryptocurrencies $\cdot$ New financial legal framework JEL Classification $\mathrm{K} 22 \cdot \mathrm{K} 24 \cdot \mathrm{K} 33$

Paweł Szwajdler

pawel.szwajdler@onet.pl

1 Institute of Law and Economics, Kazimierz Wielki University in Bydgoszcz, Pl. Weyssenhoffa 11, 85-072 Bydgoszcz, Poland 


\section{Introduction}

Initial Coin Offering (ICO) is thought to be the reason for significant future changes in financial and capital systems. ${ }^{1}$ Furthermore, it is an important method of fundraising $^{2}$ which is used worldwide by new technological start-ups. ${ }^{3}$ Nonetheless, there are no special financial regulations concerning such matters in the most significant legal systems of the world. ${ }^{4}$

A future legal framework, which should be tailored for ICO purposes, will probably lead to broader acceptance of this method of building capital. ${ }^{5}$ This revolutionary tool of capital formation, which ICO is, ${ }^{6}$ should be regulated in new legal acts because current financial regulations seem to be incompatible with the issues discussed. ${ }^{7}$

Because of the fact that ICOs are in principle cross-border, internationally standardised legal solutions concerning issues elaborated in this paper should be developed. ${ }^{8}$ With such standardisation, financial regulations in the area of ICOs will become extremely effective. However, there is no worldwide consensus concerning regulations on ICOs. ${ }^{9}$

There are two possibilities which can lead to the entry into force of standardised legal principles concerning ICO matters. The first is related to the activities of the international community. The second can be achieved by developing a legal theory of cryptocurrencies. ${ }^{10}$

In view of the fact that none of the existing significant international organisations is currently involved in developing legal solutions in the area of cryptocurrencies, ${ }^{11}$ model regulations in this field can be created only through legal research, legislative process and European legal integration. It is important to research issues regarding ICOs because the lack of well-designed regulations leads to legal uncertainty. ${ }^{12}$ This legal uncertainty could be limited by lawmakers, regulators and international actors. $^{13}$

\footnotetext{
${ }^{1}$ Dell'Erba (2018), p 1107; Rohr and Wright (2019), p 464.

2 Preston (2017-2018), p 321; Dell'Erba (2018), p 1134; Briggs (2018), p 426.

3 Trotz (2019), p 429; Meadows (2018), p 279; Debler (2018), p 253; Fitts (2019), p 927.

${ }^{4}$ See Chudinovskikh and Sevryugin (2019), pp 68, 77, 78; Gamble (2017), pp 348, 360, 361, Cvetkova (2018), pp 145-152.

${ }^{5}$ Tjio and Hu (2020); Briggs (2018), pp 426-427; Fong (2018), p 76.

${ }^{6}$ Dell'Erba (2020), p 180.

7 Yano et al. (2019), p 110; Fitts (2019), p 930; Briggs (2018), p 426; Dell'Erba (2018), p 1109.

${ }^{8}$ Briggs (2018), p 448. See also Adhami and Giudici (2019), p 68; Debler (2018), p 253; Block et al. (2020), p 2; Trotz (2019), p 455; Briggs (2018), p 448; Yano et al. (2019), p 121; Chohan (2017).

9 Briggs (2018), p 448; Yano et al. (2019), p 109; Tiwari et al. (2020), p 435; Dell'Erba (2018), p 1128.

${ }^{10}$ Cvetkova (2018), p 151. See also Dell'Erba (2018), p 1132.

11 Basaran (2019), p 773.

${ }^{12}$ Brake (2020), p 195; Adhami and Giudici (2019), p 70. See also Hönig (2018), p 24; Link and Kunz (2019), p 18; Trotz (2019), p 429; Dell'Erba (2019), p 3.

${ }^{13}$ Dell'Erba (2018), p 1134; Miller et al. (2018), p 83; Dell’Erba (2020), p 227.
} 
In view of the above, a theoretical model of regulations in the area of cryptocurrencies should be designed. The author believes that this article can lead to the development of a legal theory of ICOs.

\section{Theoretical Notion of Crypto-assets}

\subsection{General Remarks}

Crypto-assets are virtual units of value or units of account, ${ }^{14}$ which are issued in principle through Initial Coin Offering. ${ }^{15}$ They are issued using blockchain technology, ${ }^{16}$ which enables disintermediate payments, ${ }^{17}$ capital investment ${ }^{18}$ and the purchase of digital services. ${ }^{19}$

Cryptocurrencies are varied because of the fact that they involve a wide range of applicability, ${ }^{20}$ i.e. there are payment tokens, ${ }^{21}$ equity tokens, ${ }^{22}$ debt tokens ${ }^{23}$ and utility tokens. ${ }^{24}$ These types of cryptocurrencies should be discussed separately because different regulations should be created for each of these groups of crypto-assets.

\subsection{Payment Tokens}

Payment tokens ${ }^{25}$ are also known as coins. ${ }^{26}$ Such crypto-assets play a similar role as money. ${ }^{27}$ Hence, they are a medium of exchange ${ }^{28}$ and a store of value. ${ }^{29}$

\footnotetext{
14 Block et al. (2020), p 2; Maume and Fromberger (2019), p 558. See also Alkadri (2018-2019), p 77; Shulman (2020), p 58; Bratspies (2018), p 7; Howden (2015), p 763.

15 Brake (2020), pp 171, 173; Briggs (2018), p 424; Wilson (2019), p 368.

16 Essaghoolian (2019), p 299; Lockaby (2018), p 339; Crane (2018), pp 799-800.

17 Howell et al. (2018-2019), p 2.

18 See Marian (2019), p 538; O’Connor (2019), pp 539, 543; Howden (2015), p 765.

19 Howell et al. (2018-2019), pp 3-4; Clements (2018), p 77; Essaghoolian (2019), p 326; Sherman (2018), p 22.

20 Vrazel (2019), pp 529, 534; Mokhtarian and Lindgren (2018), pp 118, 119; Alvarez (2018), p 36; Shulman (2020), pp 54, 69; Marian (2019), p 538; Moran (2018), pp 238-243.

21 An et al. (2018), p 4; Howell et al. (2018-2019), p 1; Marian (2019), p 538.

22 An et al. (2018), p 4; Weber and Baisch (2019), p 15; Gurrea-Martinez and Remolina (2019), pp 6, 27; Brake (2020), p 172; Marian (2019), p 538.

23 Weber and Baisch (2019), p 15; Gurrea-Martinez and Remolina (2019), pp 6, 27.

24 Yano et al. (2019), p 116; Howell et al. (2018-2019), p 1; Block et al. (2020), p 2; Brake (2020), p 172; Weber and Baisch (2019), p 14; Higgins (2018), p 230; Marian (2019), p 538.

25 Yano et al. (2019), p 116; Howell et al. (2018-2019), p 1.

26 Vrazel (2019), p 534; Alvarez (2018), p 36; Shulman (2020), pp 54, 69.

27 Davidson (2019), p 799; Cvetkova (2018), pp 131, 134; Howden (2015), p 762; Hughes and Middlebrook (2015), p 523; Shulman (2020), p 79.

${ }^{28}$ Clements (2018), p 83; Alkadri (2018-2019), p 77; Rucker (2020), p 388; Hughes and Middlebrook (2015), p 538; Marian (2015-2016), p 55, Cvetkova (2018), p 150; Shulman (2020), p 79.

29 Part 1, Section 5 of the Australian Anti-Money Laundering and Counter-Terrorism Financing Act 2006. https://www.legislation.gov.au/Details/C2019C00011. Accessed 14 July 2021. See also Basaran (2019), p 772.
} 
Payment tokens are often described as a decentralised surrogate for money ${ }^{30}$ because they are an unofficial medium of exchange. ${ }^{31}$

Nevertheless, they are not legal tender ${ }^{32}$ (except in $\mathrm{Japan}^{33}$ ). In view of the above, it should be stated that payment tokens are not money but have only significant features of money. ${ }^{34}$

\subsection{Security Tokens}

\subsubsection{General Remarks}

Security tokens ${ }^{35}$ are also called investment tokens. ${ }^{36}$ Although they are varied, ${ }^{37}$ they can be divided into two main groups: ${ }^{38}$ debt tokens ${ }^{39}$ and equity tokens. ${ }^{40}$ Both are issued in exchange for fiat money or other cryptocurrencies. ${ }^{41}$ Equity tokens and debt tokens are discussed separately below.

\subsubsection{Equity Tokens}

Equity tokens are crypto-assets which are purchased to obtain capital flows or to gain profits related to their value changes. ${ }^{42}$ It means that they certainly have a financial nature. ${ }^{43}$

Equity tokens are similar to shares. ${ }^{44}$ In principle, they enable entitlement to dividends, ${ }^{45}$ profits, ${ }^{46}$ royalties ${ }^{47}$ and voting rights. ${ }^{48}$ Hence, they entitle their

${ }^{30}$ Davidson (2019), p 799; Cvetkova (2018), pp 131, 134; Howden (2015), p 762; Hughes and Middlebrook (2015), p 523.

${ }^{31}$ Clements (2018), p 83; Alkadri (2018-2019), p 77; Rucker (2020), p 388; Hughes and Middlebrook (2015), p 538; Marian (2015-2016), p 55; Cvetkova (2018), p 150; Shulman (2020), p 79.

32 Morton (2020), p 132; Gamble (2017), pp 350-351; Alvarez (2018), pp 39-40.

${ }^{33}$ Basaran (2019), p 765.

${ }^{34}$ Davidson (2019), p 799; Cvetkova (2018), pp 131, 134; Howden (2015), p 762; Hughes and Middlebrook (2015), p 523.

${ }^{35}$ Block et al. (2020), p 2; Higgins (2018), p 230.

${ }^{36}$ See van Beusekom (2019), p 3.

37 See Vrazel (2019), pp 535, 539, 542, 544; Hughes and Middlebrook (2015), p 528; Trotz (2019), p 434; Maume and Fromberger (2019), pp 558, 559, 567, 580; Crosser (2018), p 391; Dell'Erba (2020), p 188.

${ }^{38}$ Gurrea-Martinez and Remolina (2019), p 6.

39 van Beusekom (2019), pp 3, 11; Gurrea-Martinez and Remolina (2019), pp 6, 27; Tjio and Hu (2020).

40 van Beusekom (2019), p 3; Gurrea-Martinez and Remolina (2019), p 6.

41 van Beusekom (2019), p 14; Brake (2020), p 173.

${ }^{42}$ Crosser (2018), p 391. See also Bratspies (2018), pp 16-18; Debler (2018), pp 251-252; Maume and Fromberger (2019), p 570.

${ }^{43}$ See An et al. (2018), p 12; Liu and Wang (2019), p 126; Brake (2020), p 173.

${ }^{44}$ Vrazel (2019), p 535; Shulman (2020), pp 56, 57, 63, 69; Moran (2018), p 215.

${ }^{45}$ An et al. (2018), p 12.

${ }^{46}$ Liu and Wang (2019), p 126; Brake (2020), p 173.

${ }^{47}$ Breier et al. (2018), p 1159.

48 Adhami and Giudici (2019), p 66; Liu and Wang (2019), p 126; An et al. (2018), p 12. 
purchasers not only to typical rights of shareholders but also to rights related to e.g. royalties. $^{49}$

It is extremely important to distinguish between pure utility tokens as discussed below and equity tokens, which can have additional utilities. ${ }^{50}$ Most of all, equity tokens have a financial nature, contrary to pure utility tokens. ${ }^{51}$

\subsubsection{Debt Tokens}

The main feature of debt tokens is that they do not give entitlement to any profits or rights, but do only involve the obligation for the issuer to pay back debt. ${ }^{52}$

Consequently, these tokens are crypto-assets which are similar to debt securities. ${ }^{53}$

\subsection{Utility Tokens}

Utility tokens are issued to build the loyalty of purchasers of digital services. ${ }^{54}$ The majority of utility tokens should not be treated like securities, but there are significant exemptions, ${ }^{55}$ which are related to the financial nature of such assets. ${ }^{56}$ Nonetheless, most utility tokens have the nature of non-financial gift cards. ${ }^{57}$

Some scholars state that utility tokens are similar to payment tokens but that they can be used only to buy specific services provided by their issuers. ${ }^{58}$ However, it should be added that utility tokens have more applications than typical payment tokens. ${ }^{59}$ Therefore, utility tokens can be understood as payment tokens created for special purposes.

Some legal practitioners believe that utility tokens cannot have features of traditional financial instruments. ${ }^{60}$ However, the majority of these assets have such features $^{61}$ because issuers of utility tokens offer access to their products in exchange for capital formation. ${ }^{62}$ Therefore, it may be stated that it is difficult to create pure utility tokens.

\footnotetext{
$\overline{49}$ See Breier et al. (2018), p 1159.

50 See Lausen (2019), p 3.

51 See Clements (2018), p 83; Alkadri (2018-2019), p 77; Rucker (2020), p 388; Hughes and Middlebrook (2015), p 538.

52 See Maume and Fromberger (2019), p 570; van Beusekom (2019), p 11; Gurrea-Martinez and Remolina (2019), pp 6, 27; Tjio and $\mathrm{Hu}$ (2020).

53 See Maume and Fromberger (2019), p 570; van Beusekom (2019), p 11; Gurrea-Martinez and Remolina (2019), pp 6, 27; Tjio and $\mathrm{Hu}(2020)$.

54 Howell et al. (2018-2019), pp 3-4.

55 Lausen (2019), p 13; Essaghoolian (2019), pp 297-298.

56 See Lausen (2019), p 13; Mokhtarian and Lindgren (2018), p 129.

57 Crosser (2018), p 420.

58 Clements (2018), p 77.

59 Preston (2017-2018), p 323.

${ }^{60}$ Cvetkova (2018), p 151.

61 Debler (2018), p 258. See also Maume and Fromberger (2019), pp 560, 580; Crosser (2018), p 407; Rohr and Wright (2019), p 468.

62 Varmaz and Varmaz (2018), p 133; Dell'Erba (2020), p 180.
} 


\section{Definition of Crypto-Asset According to the Proposal for a MiCA Regulation}

\subsection{General Remarks}

The European draft definition of a crypto-asset, which is contained in the proposal for a MiCA Regulation, seems standard as it is based on the notion of 'digital representation of value or right'. ${ }^{63}$ It is easy to see that this explanation of the notion is similar to the theoretical definitions elaborated above.

Furthermore, it should also be noted that the technological aspect of the European definition of cryptocurrencies is constructed correctly. It stems from the fact that crypto-assets, within the meaning of the proposal for a MiCA Regulation, should be stored or transferred by using cryptographic technology, which is defined in an extremely wide and technologically neutral way based on similarity to DLT technology. ${ }^{64}$ Therefore, it seems difficult to avoid future applicability of the MiCA Regulation.

\subsection{Main Groups of Crypto-Assets According to the Proposal for a MiCA Regulation}

There are three main groups of crypto-assets in the proposal for a MiCA Regulation, ${ }^{65}$ namely:
a. 'asset-referenced tokens';66
b. 'electronic money tokens'; 67
c. 'utility tokens'. 68

It should also be noted that there are financial tokens which are beyond the scope of MiCA. ${ }^{69}$ Traditional European financial regulations apply to such assets. ${ }^{70}$

\footnotetext{
63 Art. 3(1)(2) of the Proposal for a Regulation of the European Parliament and of the Council on Markets in Crypto-assets, and amending Directive (EU) 2019/1937 (COM/2020/593).

${ }^{64}$ Ibid.

${ }^{65}$ See art. 3(1)(3)-(5) of the Proposal for a Regulation of the European Parliament and of the Council on Markets in Crypto-assets, and amending Directive (EU) 2019/1937 (COM/2020/593).

${ }^{66}$ Art. 3(1)(3) of the Proposal for a Regulation of the European Parliament and of the Council on Markets in Crypto-assets, and amending Directive (EU) 2019/1937 (COM/2020/593).

67 Art. 3(1)(4) of the Proposal for a Regulation of the European Parliament and of the Council on Markets in Crypto-assets, and amending Directive (EU) 2019/1937 (COM/2020/593).

${ }^{68}$ Art. 3(1)(5) of the Proposal for a Regulation of the European Parliament and of the Council on Markets in Crypto-assets, and amending Directive (EU) 2019/1937 (COM/2020/593).

${ }^{69}$ Noble (2020), pp 14-15; Zetzsche et al. (2020), p 21.

${ }^{70}$ Ferrari (2020), p 340. See also Kapsis (2020), p 19; Zetzsche et al. (2020), p 21.
} 
Therefore, even if the MiCA Regulation enters into force, there may be tokens which would not be explicitly regulated in any European regulation. ${ }^{71}$ Hence, MiCA tokens and non-MiCA crypto-assets should be distinguished for theoretical and practical purposes.

Because of the fact that only certain crypto-assets would fall within the scope of the proposal for a MiCA Regulation, the creation of uniform European regulation for crypto-asset purposes should be considered. ${ }^{72}$

Although the latter solution seems justified and correct, it may turn out to be extremely difficult. This is due to the variety of crypto-assets. ${ }^{73}$ However, it will probably be necessary to create general regulation in the field of crypto-assets in the next phase of harmonisation of these matters.

In the current legal and factual situation in the European Union, two groups of crypto-assets should be discussed separately. The first concerns cryptocurrencies which fall within the scope of the proposal for a MiCA Regulation. The second consists of tokens to which traditional European financial regulations apply.

\subsection{Tokens Beyond the Scope of MiCA}

It should be repeated that most financial tokens do not fall within the scope of the proposal for a MiCA Regulation. In principle, such tokens are financial cryptoassets, which meet transferability criteria defined in general financial European regulations. ${ }^{74}$ Hence, the MiCA Regulation would not be applied to crypto-assets that are transferable securities because issues relating to such assets are regulated in other European normative acts. ${ }^{75}$

The above-mentioned legal solution related to financial transferable crypto-assets is similar to a 'wait and see' approach. Such a legal solution will be justified until the entry into force of a general European legal act in the field of crypto-assets which would apply to both financial and non-financial tokens.

The main problem related to financial crypto-assets is that the transferability of such assets should be tested in a precise manner. Theoretically, the features of financial crypto-assets are similar to those of 'analogous' financial instruments. ${ }^{76}$

Moreover, special regulations designed for financial crypto-asset purposes could turn out to be discriminative or favourable. This means that such legal provisions would be incompatible with the European legal system.

\footnotetext{
71 Ferrari (2020), pp 340-341.

72 See Mathis (2020), p 11.

73 See Vrazel (2019), pp 535, 539, 542, 544; Hughes and Middlebrook (2015), p 528; Trotz (2019), p 434; Maume and Fromberger (2019), pp 558, 559, 567, 580; Crosser (2018), p 391; Dell'Erba (2020), p 188.

${ }^{74}$ Ferrari (2020), pp 330-332, 335.

75 See Zetzsche et al. (2020), p 21.

76 See Ferrari (2020), pp 330-332, 335.
} 
Furthermore, there is the risk of legal competition between Member States ${ }^{77}$ because national regulators and legislators are in principle free to create crypto-asset legal provisions. Therefore, such provisions can differ between Member States. ${ }^{78}$

\subsection{Tokens Within the Scope of MiCA}

\subsubsection{Asset-referenced Tokens}

'Asset-referenced tokens' are asset-backed tokens, ${ }^{79}$ which seem to be crypto derivatives. The value of such instruments should be based on the value of:
a. several fiat currencies; or
b. at least one other crypto-asset; or
c. at least one commodity. ${ }^{80}$

In view of the above, asset-referenced tokens are linked with various groups of assets, i.e. the following crypto-derivatives should be distinguished:
a. currency crypto derivatives;
b. tokenised crypto derivatives; and
c. commodity crypto derivatives.

\subsubsection{E-money Tokens}

E-money MiCA tokens can be defined as a stable medium of exchange based on fiat currencies. ${ }^{81}$ This definition seems extremely narrow because these tokens are understood in a wider sense by legal theoreticians. ${ }^{82}$

E-money tokens, which are proposed to be regulated in MiCA, would have to be authorised by a competent authority. ${ }^{83}$ Furthermore, they should be issued only by an 'electronic money institution' or a 'credit institution'. ${ }^{84}$

The above definition has been constructed for the applicability of the MiCA Regulation. Coins based on fiat currencies should be regulated in European legal acts because they can influence currency stability and are substitutes of fiat currencies.

\footnotetext{
77 Ibid., p 341.

78 Mathis (2020), pp 9-10.

79 See art. 3(1)(3) of the Proposal for a Regulation of the European Parliament and of the Council on Markets in Crypto-assets, and amending Directive (EU) 2019/1937 (COM/2020/593).

80 Ibid.

81 See art. 3(1)(4) of the Proposal for a Regulation of the European Parliament and of the Council on Markets in Crypto-assets, and amending Directive (EU) 2019/1937 (COM/2020/593).

82 See Clements (2018), p 83; Alkadri (2018-2019), p 77; Rucker (2020), p 388; Hughes and Middlebrook (2015), p 538; Marian (2015-2016), p 55; Cvetkova (2018), p 150; Shulman (2020), p 79.

83 Art. 43(1)(a) of the Proposal for a Regulation of the European Parliament and of the Council on Markets in Crypto-assets, and amending Directive (EU) 2019/1937 (COM/2020/593).

84 Ibid.
} 
Still, it would also be reasonable to regulate in European legal acts coins which are not based on fiat currencies. However, this will probably be done in a future phase of harmonisation of crypto-asset issues.

\subsubsection{Utility Tokens}

According to the proposal for a MiCA Regulation, a utility token is a crypto-asset which can be used only to buy particular goods or services. ${ }^{85}$ Such a token should be accepted only by its issuer. ${ }^{86}$

It is important to state that this definition is completely compatible with the above-mentioned notion of utility tokens constructed by legal theoreticians. ${ }^{87}$ Therefore, this issue need not to be elaborated separately or in detail in this subsection. ${ }^{88}$

\subsubsection{Significant Tokens}

According to the proposal for a MiCA Regulation, e-money tokens and asset-referenced tokens can be significant within the meaning of the discussed draft legal act. ${ }^{89}$

The notion of significance is based on a number of criteria such as:

a. the number of customers to whom crypto-assets will be offered;

b. the value of the crypto-assets issued;

c. the number of transactions related to those crypto-assets;

d. the size of the issuer's reserve of assets;

e. the cross-border nature of the issuer's activity; and

f. the connection between the significant crypto-assets and the financial market. ${ }^{90}$

Special regulations in the proposal for a MiCA would apply to significant assetreferenced tokens and e-money tokens. ${ }^{91}$ It is a good solution because the issuance of such assets should be related to particular obligations and principles as these instruments can play an important role in the European crypto market.

\footnotetext{
85 Art. 3(1)(5) of the Proposal for a Regulation of the European Parliament and of the Council on Markets in Crypto-assets, and amending Directive (EU) 2019/1937 (COM/2020/593).

86 Ibid.

87 See Howell et al. (2018-2019), pp 3-4; Crosser (2018), p 420.

${ }^{88}$ See subsection 2.4 of this article.

89 Arts. 39 and 50 of the Proposal for a Regulation of the European Parliament and of the Council on Markets in Crypto-assets, and amending Directive (EU) 2019/1937 (COM/2020/593).

90 Ibid.

91 Arts. 41 and 52 of the Proposal for a Regulation of the European Parliament and of the Council on Markets in Crypto-assets, and amending Directive (EU) 2019/1937 (COM/2020/593).
} 


\section{Notion of Initial Coin Offering}

\subsection{General Remarks}

Initial Coin Offering is alternatively called Token Generating Event, ${ }^{92}$ Initial Crypto-asset Offering, ${ }^{93}$ Security Token Offering, ${ }^{94}$ Initial Issuance of Tokens ${ }^{95}$ and Initial Membership Offering. ${ }^{96}$ Each of these names is justified, but using the most common notion, namely Initial Coin Offering (ICO), is preferable and clear.

There is no common definition of Initial Coin Offering. ${ }^{97}$ Nonetheless, ICO is undoubtedly an alternative method of capital formation ${ }^{98}$ and is regarded as a modern and innovative tool ${ }^{99}$ used for capital formation purposes. ${ }^{100}$

Initial Coin Offering is a process designed for issuing new crypto-assets. ${ }^{101}$ The mechanism is defined as the selling of digital assets to the public in exchange for money or other cryptocurrencies. ${ }^{102}$ This process is of a digital, ${ }^{103}$ virtual $^{104}$ and online nature. ${ }^{105}$ It should also be noted that ICO is more than only a fundraising method. ${ }^{106}$ In particular, ICO can be used to create new digital assets ${ }^{107}$ which have additional utilities. ${ }^{108}$ Hence, ICOs should be regulated separately in new legal acts.

Through this method of capital formation, crypto-assets are sold to a wide range of investors. ${ }^{109}$ Hence, ICO is similar to IPO which is organised for issuing traditional financial instruments. ${ }^{110}$ Some scholars even claim that each ICO is an unregulated IPO. ${ }^{111}$ However, this is not a correct statement because there are many differences between ICOs and IPOs. ${ }^{112}$ Therefore, a distinction should be made between these two financial processes.

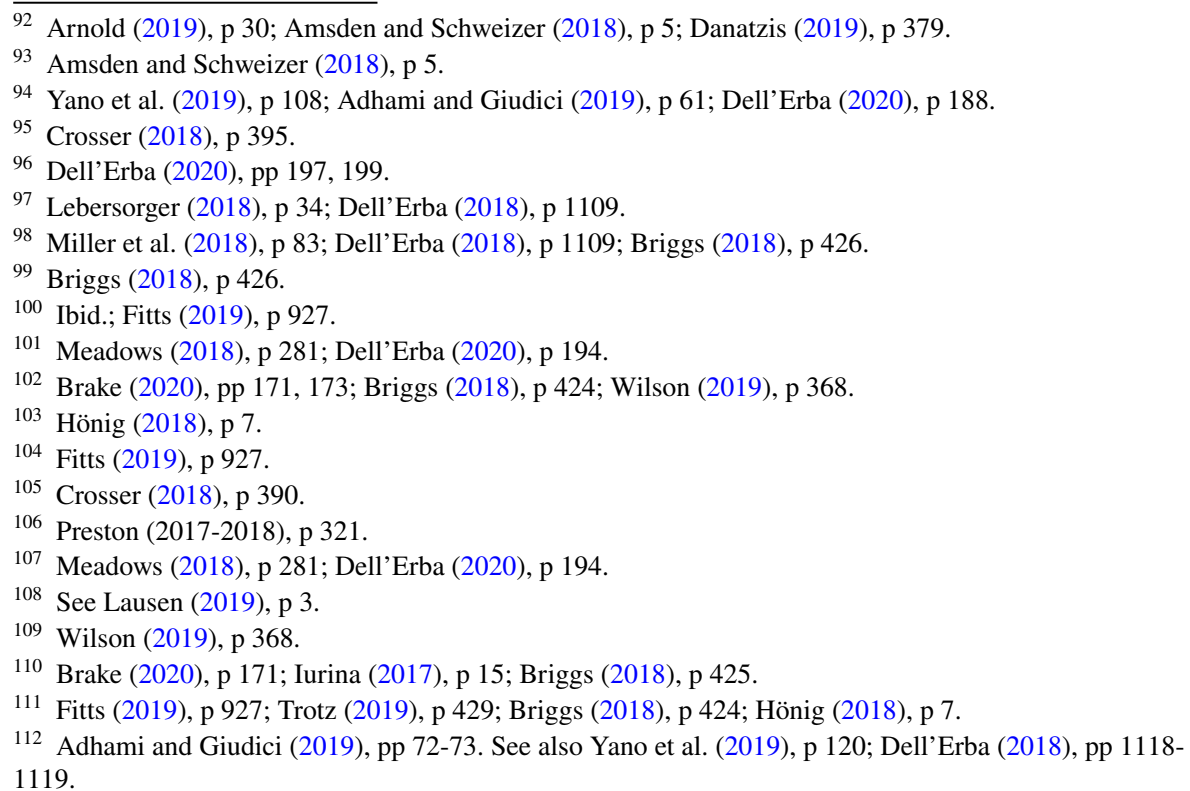


ICOs are used especially to finance new projects, ideas and start-ups. ${ }^{113}$ However, well-established companies ${ }^{114}$ also organise ICOs to avoid regulations concerning IPOs. ${ }^{115}$ Therefore, it should be considered whether a new legal framework in the area of crypto-assets should be designed in such a way as to make it difficult or even impossible for traditional companies to organise ICOs.

\subsection{Phases of Initial Coin Offering}

ICOs are divided in phases. ${ }^{116}$ According to most scholars, there are three main phases of ICO: the pre-ICO phase, the real ICO phase and the post-ICO phase. ${ }^{117}$ Some researchers distinguish analogous phases: the 'white paper' phase, the primary market phase and the secondary market phase. ${ }^{118}$ Properly constructed new legal regulations in the field of ICOs should be based on this division

In the pre-ICO phase, issuers create ideas and plans related to tokens. ${ }^{119}$ During this phase, tokens are designed ${ }^{120}$ and a white paper is prepared. ${ }^{121}$ In this phase, the white paper should be audited ${ }^{122}$ and the credibility of the issuer should be checked by the regulator. ${ }^{123}$

In the primary market phase, crypto-assets are issued and sold to the public. ${ }^{124}$ This phase is essential for the success of the Initial Coin Offering. Tokens are sold in exchange for fiat currencies or crypto-assets. ${ }^{125}$

The post-ICO phase is related to the secondary market. ${ }^{126}$ This phase is extremely important for the stability of the crypto-asset market. New financial regulations concerning the post-ICO phase should be focused on the functioning of cryptoexchanges $^{127}$ and the fulfilment of disclosure and reporting obligations by issuers. ${ }^{128}$

\footnotetext{
113 Miller et al. (2018), p 85; Howell et al. (2018-2019), p 1; Varmaz and Varmaz (2018), p 130; Hönig (2018), p 24; Trotz (2019), p 429; Meadows (2018), p 279; Moran (2018), p 214.

114 Howell et al. (2018-2019), p 1; Moran (2018), p 214.

115 See Higgins (2018), p 221; Essaghoolian (2019), p 296; Moran (2018), p 214; Tjio and Hu (2020).

116 See Steverding and Zureck (2020), p 19; Adhami and Giudici (2019), p 63.

117 Ibid.

118 Varmaz and Varmaz (2018), p 132.

119 Steverding and Zureck (2020), p 19

120 Ibid., p 20.

121 Gurrea-Martinez and Remolina (2019), p 9.

122 Tiwari et al. (2020), p 435; Gurrea-Martinez and Remolina (2019), p 14.

123 See Maume and Fromberger (2019), pp 567-568.

124 Wilson (2019), p 368; Briggs (2018), p 424.

125 van Beusekom (2019), p 14; Brake (2020), p 173.

126 Steverding and Zureck (2020), p 27.

127 See Dell'Erba (2020), p 213; Trotz (2019), p 446; Steverding and Zureck (2020), p 27.

128 See Yano et al. (2019), p 109; Tiwari et al. (2020), p 438; Adhami and Giudici (2019), p 70; Howell et al. (2018-2019), p 14; MacNiven (2018-2019), p 7; Fong (2018), p 75; Preston (2017-2018), p 330; O'Connor (2019), p 564.
} 


\subsection{Smart Contracts}

Agreements concerning ICOs are often reached by using digital tools called smart contracts, which are programmable digital codes. ${ }^{129}$ It is obvious that traditional ways of entering into contracts are not used in the case of completely digital assets.

In general, smart contracts are used to connect two persons (in the case of ICOs: issuer and investor) in order to achieve an agreement ${ }^{130}$ which can be automatically executed. ${ }^{131}$ However, this tool has many additional utilities. For instance, it makes it possible to programme transactions ${ }^{132}$ and their rules. ${ }^{133}$ Furthermore, smart contracts can be used to design tokens ${ }^{134}$ and generate crypto-assets. ${ }^{135}$ They can also be used as tools enabling investors to vote. ${ }^{136}$

Because of the fact that smart contracts are pure IT tools, replacement of classical agreements by digital codes is thought to be extremely difficult. ${ }^{137}$ However, it should be regulated that entering into a smart contract is legally binding and has the same effect as concluding a traditional agreement. ${ }^{138}$ For instance, smart contracts are not regarded as legally binding agreements in Germany. ${ }^{139}$ In that country, investors who did not sign a traditional agreement in writing cannot be protected by German general and traditional legal regulations. ${ }^{140}$ Hence, issues regarding smart contracts should be regulated in new financial regulations so as to ensure protection of investors.

\section{Current Legal Framework}

\subsection{General Remarks}

There are a number of legal approaches to the discussed issues in contemporary legal systems. ${ }^{141}$ For instance, ICOs are banned in China and South Korea. ${ }^{142}$ In

\footnotetext{
${ }^{129}$ Olivier and Jaccard (2017), p 3; Lausen (2019), p 3; Varmaz and Varmaz (2018), p 3; Meadows (2018), p 281; Knecht (2017-2018), p 8.

130 Olivier and Jaccard (2017), p 4; Lausen (2019), p 3.

131 See Olivier and Jaccard (2017), p 3; Crosser (2018), p 386.

${ }^{132}$ Lausen (2019), p 3.

${ }^{133}$ Knecht (2017-2018), p 8.

134 Rohr and Wright (2019), p 474; Amsden and Schweizer (2018), p 8; Marian (2015-2016), p 55.

${ }^{135}$ Knecht (2017-2018), p 8; Amsden and Schweizer (2018), p 8; Marian (2015-2016), p 55.

136 Rohr and Wright (2019), p 476.

137 Walker (2019), p 2.

138 Ibid., pp 1-2. See also Adhami and Giudici (2019), p 61.

139 Varmaz and Varmaz (2018), p 135.

140 Ibid.

${ }^{141}$ Chudinovskikh and Sevryugin (2019), p 64; Marian (2019), p 564; Basaran (2019), p 766.

142 Shulman (2020), p 75; Vrazel (2019), p 530; Mokhtarian and Lindgren (2018), p 151; Moran (2018), pp 249-250.
} 
most countries, traditional financial ${ }^{143}$ and civil ${ }^{144}$ regulations are applicable to issues regarding cryptocurrencies. ${ }^{145}$ Examples of such countries are the USA, Australia and the UK. ${ }^{146}$ There are also countries with special regulations for cryptoassets, ${ }^{147}$ e.g. France, ${ }^{148}$ Gibraltar ${ }^{149}$ and Malta. ${ }^{150}$ Special Maltese and French regulations apply for instance to ICO issues. ${ }^{151}$

\subsection{Applicability of Traditional Financial Regulations}

In some countries, traditional financial regulations (especially regulations concerning IPOs) are applicable to ICOs. ${ }^{152}$ This stems from the assumption that some tokens have most of the features of traditional financial instruments, ${ }^{153}$ which is related to the fact that ICOs are based on IPOs. ${ }^{154}$ However, traditional regulations are ineffective in the case of such matters ${ }^{155}$ because the differences between traditional financial instruments and digital assets are significant. ${ }^{156}$ Therefore, it is high time to regulate ICO issues separately.

\footnotetext{
143 Gurrea-Martinez and Remolina (2019), p 31; Liu and Wang (2019), p 127; Wilson (2019), p 367; Briggs (2018), p 439.

144 van Beusekom (2019), p 2.

145 Gurrea-Martinez and Remolina (2019), p 31; Liu and Wang (2019), p 127; Wilson (2019), p 367; Briggs (2018), p 439; van Beusekom (2019), p 2.

${ }^{146}$ See the introduction to the Australian ASIC's information sheet (INFO 225) on initial coin offerings and crypto-assets. https://asic.gov.au/regulatory-resources/digital-transformation/initial-coin-offeringsand-crypto-assets/\#part-a. Accessed 14 July 2021. See also O'Connor (2019), p 568.

147 Stacher (2018), pp 31-34; Weber and Baisch (2019), p 18; Arnold (2019), p 63; Tiwari et al. (2020), p 435; Walker (2019), pp 6-7.

148 Arts. L552-1-L552-7 of the French Code monétaire et financier. https://www.legifrance.gouv.fr/ codes/section_lc/LEGITEXT000006072026/LEGISCTA000038509541/\#LEGISCTA000038509541. Accessed 14 July 2021.

149 Stacher (2018), pp 31-34; Weber and Baisch (2019), p 18; Arnold (2019), p 63; Kaal (2018), p 53; Marian (2019), p 552.

150 Tiwari et al. (2020), p 435; Walker (2019), pp 6-7; Marian (2019), p 551.

151 Arts. 3-12 of the Maltese Virtual Financial Assets Act 2018. https://legislation.mt/eli/cap/590/eng/ pdf. Accessed 14 July 2021. See also Art. L552-3 of the French Code monétaire et financier. https:// www.legifrance.gouv.fr/codes/section_lc/LEGITEXT000006072026/LEGISCTA000038509541/\#LEGIS CTA000038509541. Accessed 14 July 2021.

152 Gurrea-Martinez and Remolina (2019), p 31; Liu and Wang (2019), p 127; Wilson (2019), p 367; Briggs (2018), p 439; Lebersorger (2018), p 29; Kaal (2018), pp 47-48.

${ }^{153}$ Danatzis (2019), p 20.

154 Vrazel (2019), pp 546, 550. See also Fitts (2019), p 927; Trotz (2019), p 429; Briggs (2018), p 424; Hönig (2018), p 7.

155 Gurrea-Martinez and Remolina (2019), p 31; Yano et al. (2019), p 110; Briggs (2018), p 439; Hönig (2018), p 3.

156 Tjio and $\mathrm{Hu}$ (2020). See also Adhami and Giudici (2019), pp 72-73; Yano et al. (2019), p 120; Dell'Erba (2018), pp 1118-1119.
} 


\subsection{Applicability of General Contract Law}

There are countries where general contract law applies to ICOs. ${ }^{157}$ This is justified until smart contracts are treated as typical 'analogous' agreements (viz. a contract between issuer and investor is understood as a contract of sale ${ }^{158}$ or a barter contract). ${ }^{159}$ A contract of sale enters into force when cryptocurrencies are issued in exchange for fiat currencies, ${ }^{160}$ whereas a barter contract is signed if crypto-assets are issued in exchange for other tokens. ${ }^{161}$

The application of general contract law to matters relating to crypto-assets is undoubtedly justified in the case of non-security tokens. Furthermore, general contract law can be applied to issues that are not regulated in traditional financial regulations.

\subsection{Applicability of General Consumer Law}

In some countries, regulations in the area of consumer law are applicable to issues regarding crypto-asset manipulation. ${ }^{162}$ Such legal provisions apply to both security and non-security tokens. ${ }^{163}$

The discussed regulations should definitely be applicable to utility tokens without any exemptions. However, in the case of security tokens, legal provisions in the field of consumer law apply only to issues not regulated under general financial law until the moment special regulations on financial tokens enter into force.

In the case of European law, consumer protection regulations enacted under the general Market Abuse Regulation (MAR II) ${ }^{164}$ are applicable to all kinds of financial tokens. ${ }^{165}$ This is in line with the European 'Digital Finance Strategy'. ${ }^{166}$ However, it would be more accurate to separately regulate the protection of European investors who purchase transferable tokens through ICOs.

\footnotetext{
157 van Beusekom (2019), p 12; Gurrea-Martinez and Remolina (2019), pp 17, 19.

158 van Beusekom (2019), p 12; Lebersorger (2018), p 29.

159 van Beusekom (2019), p 12.

160 van Beusekom (2019), p 12; Lebersorger (2018), p 29.

161 van Beusekom (2019), p 12.

162 See the introduction to the Australian ASIC's information sheet (INFO 225) on initial coin offerings and crypto-assets. https://asic.gov.au/regulatory-resources/digital-transformation/initial-coin-offeringsand-crypto-assets/\#part-a. Accessed 14 July 2021. See also Mathis (2020), p 10; Noble (2020), p 12; Zetzsche et al. (2020), pp 3-4.

163 Part B of the Australian ASIC's information sheet (INFO 225) on initial coin offerings and cryptoassets. https://asic.gov.au/regulatory-resources/digital-transformation/initial-coin-offerings-and-cryptoassets/\#part-a. Accessed 14 July 2021. See also Mathis (2020), p 10.

164 Regulation (EU) No 596/2014 of the European Parliament and of the Council of 16 April 2014 on market abuse (market abuse regulation) and repealing Directive 2003/6/EC of the European Parliament and of the Council and Commission Directives 2003/124/EC, 2003/125/EC and 2004/72/EC.

165 Mathis (2020), p 10.

166 Zetzsche et al. (2020), pp 3-4.
} 


\subsection{Regulators' Guidelines}

Some countries have non-binding guidelines related to issues regarding cryptoassets, created by regulators. ${ }^{167}$ Such guidelines are useful for issuers because the applicability of current general financial regulations in these matters is explained in such documents. ${ }^{168}$

The main disadvantage of these guidelines is that activity compatible with such guidelines cannot guarantee that issuers, developers and other operators do not breach the law.

\subsection{Regulators' Warnings}

Although in most countries ICO issues are not yet regulated, many regulators publish warnings about this method of fundraising. ${ }^{169}$ They can be useful not only for investors but also for issuers.

However, such warnings are extremely general and non-binding because regulators focus on indicating certain issues instead of solving existing problems. ${ }^{170}$ Therefore, regulations should be created which limit the liability of persons who act in accordance with these warnings.

\subsection{Innovation Hubs}

Interesting examples of regulators' support for crypto-asset companies are innovation hubs, ${ }^{171}$ such as, for instance, the Australian innovation hub. ${ }^{172}$ Innovation hubs are used to give issuers and other crypto-asset entrepreneurs non-binding advice on the applicability of traditional legal regulations. ${ }^{173}$ They are useful because they lend particular advice concerning matters regarding cryptocurrencies. ${ }^{174}$

Some scholars are even of the opinion that in the area of cryptocurrencies innovation hubs should be created instead of legal regulations. ${ }^{175}$ In that case, legal rules

\footnotetext{
167 Miller et al. (2018), p 91.

168 See the Australian ASIC's information sheet (INFO 225) on initial coin offerings and crypto-assets. https://asic.gov.au/regulatory-resources/digital-transformation/initial-coin-offerings-and-crypto-assets/\# part-a. Accessed 14 July 2021.

169 Dell'Erba (2018), p 1124; Allen (2020), pp 11, 13; Maume and Fromberger (2019), p 567; Lausen (2019), p 5.

170 See the Australian ASIC's information sheet (INFO 225) on initial coin offerings and crypto-assets. https://asic.gov.au/regulatory-resources/digital-transformation/initial-coin-offerings-and-crypto-assets/\# part-a. Accessed 14 July 2021.

171 Weber and Baisch (2019), p 13.

172 The Australian ASIC's sheet entitled: Innovation hub: practical support and informal assistance. https://asic.gov.au/for-business/innovation-hub/. Accessed 14 July 2021.

173 Ibid.

174 Ibid.

175 Weber and Baisch (2019), p 13.
} 
which limit the liability of operators using support offered through innovation hubs should be developed.

\subsection{Construction of Maltese Regulations in the Field of ICOs}

Malta is a country where regulations on ICOs are in force. ${ }^{176}$ These legal provisions are enacted in the Virtual Assets Act 2018, ${ }^{177}$ which should be briefly discussed in this part of the article.

According to these regulations, the initial offering of virtual financial assets under Maltese jurisdiction must be preceded by the issuance and registration of a white paper which should comply with the principles defined, among others, in the First Schedule to the Virtual Financial Assets Act 2018. ${ }^{178}$ According to this Act, the principles defined by the regulator are applicable to the information published on issuers' websites. ${ }^{179}$ There are also special regulations related to ICO advertisements. ${ }^{180}$

Although Malta has jurisdiction for a wide range of disintermediated factual situations related to ICOs, in the case of cross-border Initial Token Offerings, the legal regulations, which are in force at the location of the crypto-exchange involved in the crypto-asset trade, should be applied. ${ }^{181}$

Crypto-asset undertakings should obtain a special licence and be registered in order to fulfil the Maltese legal requirements related to ICOs. ${ }^{182}$ Furthermore, a special agent should be appointed in the case of tokens issued under Maltese jurisdiction. ${ }^{183}$ Such agent's main obligation is to ensure accordance of an ICO with Maltese legal regulations. ${ }^{184}$

\footnotetext{
176 Arts. 3-12 of the Maltese Virtual Financial Assets Act 2018. https://legislation.mt/eli/cap/590/eng/ pdf. Accessed 14 July 2021.

177 The Maltese Virtual Financial Assets Act 2018. https://legislation.mt/eli/cap/590/eng/pdf. Accessed 14 July 2021.

178 Arts. 3(1) and 4 of the Maltese Virtual Financial Assets Act 2018. https://legislation.mt/eli/cap/590/ eng/pdf. Accessed 14 July 2021.

${ }^{179}$ Art. 5 of the Maltese Virtual Financial Assets Act 2018. https://legislation.mt/eli/cap/590/eng/pdf. Accessed 14 July 2021.

${ }^{180}$ Art. 6 of Maltese Virtual Financial Assets Act 2018. https://legislation.mt/eli/cap/590/eng/pdf. Accessed 14 July 2021.

181 Arts. 11, 12 and 13 of the Maltese Virtual Financial Assets Act 2018. https://legislation.mt/eli/cap/ 590/eng/pdf. Accessed 14 July 2021.

${ }^{182}$ Arts. 13-16 of the Maltese Virtual Financial Assets Act 2018. https://legislation.mt/eli/cap/590/eng/ pdf. Accessed 14 July 2021.

${ }^{183}$ Art. 7 of the Maltese Virtual Financial Assets Act 2018. https://legislation.mt/eli/cap/590/eng/pdf. Accessed 14 July 2021.

${ }^{184}$ Art. 7(1)(a) of the Maltese Virtual Financial Assets Act 2018. https://legislation.mt/eli/cap/590/eng/ pdf. Accessed 14 July 2021.
} 
The Maltese Virtual Financial Assets Act 2018 also contains detailed anti-manipulation measures. ${ }^{185}$ They concern the prohibition of insider dealing and abusive strategies related to crypto-assets. ${ }^{186}$

The Maltese legislator has also regulated issues related to audit requirements and liability of crypto-asset undertakings. ${ }^{187}$ In view of the above, the Maltese financial system has undoubtedly been designed to ensure protection of crypto-asset investors.

\subsection{Construction of French Regulations in the Field of ICOs}

\subsubsection{General Remarks}

Legal regulations in the field of ICOs are also in force in France. ${ }^{188}$ ICO issues are regulated in the French Code monétaire et financier. ${ }^{189}$ The legal provisions are extremely general. They contain definitions of:

a. tokens ('jetons'); ${ }^{190}$ and

b. public offering of crypto-assets. ${ }^{191}$

Furthermore, issues regarding informative documents ${ }^{192}$ and authorisation related to tokens ${ }^{193}$ are also regulated in this legal act.

\footnotetext{
185 Arts. 33-37 of the Maltese Virtual Financial Assets Act 2018. https://legislation.mt/eli/cap/590/eng/ pdf. Accessed 14 July 2021.

186 Arts. 34-37 of the Maltese Virtual Financial Assets Act 2018. https://legislation.mt/eli/cap/590/eng/ pdf. Accessed 14 July 2021.

187 Arts. 50-58 of the Maltese Virtual Financial Assets Act 2018. https://legislation.mt/eli/cap/590/eng/ pdf. Accessed 14 July 2021.

188 Arts. L552-1-L552-7 of the French Code monétaire et financier. https://www.legifrance.gouv.fr/ codes/section_1c/LEGITEXT000006072026/LEGISCTA000038509541/\#LEGISCTA000038509541. Accessed 14 July 2021.

189 Ibid.

190 Art. L552-2 of the French Code monétaire et financier. https://www.legifrance.gouv.fr/codes/secti on_lc/LEGITEXT000006072026/LEGISCTA000038509541/\#LEGISCTA000038509541. Accessed 14 July 2021.

191 Art. L552-3 of the French Code monétaire et financier. https://www.legifrance.gouv.fr/codes/secti on_lc/LEGITEXT000006072026/LEGISCTA000038509541/\#LEGISCTA000038509541. Accessed 14 July 2021.

192 Art. L552-4 of the French Code monétaire et financier. https://www.legifrance.gouv.fr/codes/secti on_lc/LEGITEXT000006072026/LEGISCTA000038509541/\#LEGISCTA000038509541. Accessed 14 July 2021.

193 Arts. L552-1 and L552-4-L552-6 of the French Code monétaire et financier. https://www.legifrance. gouv.fr/codes/section_lc/LEGITEXT000006072026/LEGISCTA000038509541/\#LEGISCTA0000385 09541. Accessed 14 July 2021.
} 


\subsubsection{Definition of Tokens}

Under the French regulations, tokens are digital intangible assets which are registered virtually. ${ }^{194}$ This definition seems correctly constructed because it is general and technologically neutral. However, it may turn out to be too broad in certain factual situations.

\subsubsection{Notion of Public Offering of Tokens}

The notion of ICO is not explicitly used in French regulations. The legal act in question contains a definition of public offering of tokens. ${ }^{195}$ The notion is related to the offering of crypto-assets to the public through the mechanism of subscription. ${ }^{196}$

The definition does not seem to be of a cryptographic and digital nature, but may prove useful. It is also technologically neutral and may therefore have practical value. Still, it should not be used in legal research.

\subsubsection{Authorisation and Other Issues Regulated in French Legal Provisions}

Each public offering of tokens should be authorised by the French financial supervisory authority (AMF). ${ }^{197}$ In view of this fact, it is obvious that the issuance of crypto-assets is being supervised. The scope of this supervision is specified. ${ }^{198}$

According to the French regulations, the competent supervisory authority is obliged to:

a. examine if the issuer is reliable;

b. confirm if the issuer is a legal entity; and

c. check if the assets of the issuer are properly monitored and protected. ${ }^{199}$

\footnotetext{
${ }^{194}$ Art. L552-2 of the French Code monétaire et financier. https://www.legifrance.gouv.fr/codes/secti on_lc/LEGITEXT000006072026/LEGISCTA000038509541/\#LEGISCTA000038509541. Accessed 14 July 2021.

195 Art. L552-3 of the French Code monétaire et financier. https://www.legifrance.gouv.fr/codes/secti on_lc/LEGITEXT000006072026/LEGISCTA000038509541/\#LEGISCTA000038509541. Accessed 14 July 2021.

${ }^{196}$ Ibid.

197 Art. L552-4 of the French Code monétaire et financier. https://www.legifrance.gouv.fr/codes/secti on_lc/LEGITEXT000006072026/LEGISCTA000038509541/\#LEGISCTA000038509541. Accessed 14 July 2021.

198 Art. L552-5 of the French Code monétaire et financier. https://www.legifrance.gouv.fr/codes/secti on_lc/LEGITEXT000006072026/LEGISCTA000038509541/\#LEGISCTA000038509541. Accessed 14 July 2021.

199 Ibid. 
Furthermore, French issuers of tokens must publish documents containing useful information on the issuance of crypto-assets. ${ }^{200}$ Disclosure obligations of French crypto issuers are specified in general financial regulations, ${ }^{201}$ but, as stated, the disclosure of useful information is regulated separately. ${ }^{202}$

\subsubsection{Opinion on the French Legal Provisions on ICOs}

The French legal provisions on crypto-assets seem extremely general. They do not have any especially designed features to deal with legal situations related to cryptoassets. The same regulations could be created for traditional financial instruments. They were probably enacted only to explicitly regulate that the issuance of cryptoassets should be authorised and supervised by the French financial authority.

\section{General Remarks on the European Approach to Crypto-asset Issues}

The European approach to crypto-asset issues is still evolving. In general, the European ideas related to such matters seem similar to the above-mentioned concepts common in legal research (also outside the European Union).

Most of all, it should be stated that the European institutions aim to develop legal solutions related to crypto-assets and 'digital revolution'. ${ }^{203}$ The main example of this approach is the publication of the proposal for a MiCA Regulation which is planned to be applicable only to utility tokens, e-money tokens and other cryptoassets that do not meet the transferability criteria. ${ }^{204}$

In the case of entry into force of the MiCA Regulation, future European legal provisions in the field of crypto-assets would be based on separate approaches related to particular types of assets and specified groups of entities. ${ }^{205}$ Hence, the MiCA Regulation would lead to fragmentation of legal approaches to different crypto-assets. ${ }^{206}$ Furthermore, in the MiCA proposal, issuers and crypto-service providers are governed by different regulations. ${ }^{207}$ This is related to the fact that the legal and factual situations of these groups greatly differ.

Reconciliation between new technologies and traditional financial provisions is thought to be problematic. ${ }^{208}$ Therefore, general European financial regulations

\footnotetext{
200 Art. 552-4 of the French Code monétaire et financier. https://www.legifrance.gouv.fr/codes/section_ 1c/LEGITEXT000006072026/LEGISCTA000038509541/\#LEGISCTA000038509541. Accessed 14 July 2021.

201 Ibid.

202 Ibid.

203 Noble (2020), p 19. See also Kapsis (2020), p 22.

204 Zetzsche et al. (2020), p 10; Noble (2020), pp 5, 13-15.

205 See Noble (2020), pp 6-8.

206 Ibid., pp 1, 6, 7, 11.

207 Arts. 1(b), 57 and 59 of the Proposal for a Regulation of the European Parliament and of the Council on Markets in Crypto-assets, and amending Directive (EU) 2019/1937 (COM/2020/593).

208 Noble (2020), pp 2-4.
} 
have to apply to tokens, which are transferable securities, also if the MiCA Regulation enters into force. ${ }^{209}$ This distinction between transferable and non-transferable tokens will lead to further fragmentation of crypto-asset issues in the European legal system. ${ }^{210}$ Such a construction of European legal provisions relating to crypto-assets should be temporary. It will probably exist until European general crypto-asset regulations enter into force.

\section{Role of the International Community in the Process of Creating Standardised Financial Regulations in the Area of Cryptocurrencies}

\subsection{General Remarks}

It is difficult to develop effective national regulations in the area of ICOs. ${ }^{211}$ Many scholars are therefore of the opinion that it is necessary to design an international legal system concerning ICOs and other issues related to cryptocurrencies. ${ }^{212}$ This stems from the justified idea that financial regulations concerning ICOs should be internationally standardised. ${ }^{213}$

However, none of the significant international organisations is currently involved in coordinating the creation of such regulations. ${ }^{214}$ Therefore, a new international organisation should be set up that would be competent in crypto-asset matters. Under the auspices of such an organisation, a new international legal system for cryptocurrencies could be developed.

\subsection{Treaties on Matters of Cryptocurrencies}

The above-mentioned international organisation should play a significant role in the preparation of an international treaty on cryptocurrency matters. Such a treaty would lead to uniformity of legal provisions concerning cryptocurrencies and ICOs. The most important regulations of this treaty should be legal provisions related to jurisdiction in matters of crypto-assets. ${ }^{215}$

The international legal system should provide for bilateral treaties on the exchange of information in these matters so as to provide for effective countermeasures against international crypto-asset manipulation and money laundering. ${ }^{216}$

\footnotetext{
209 See Zetzsche et al. (2020), p 21.

210 See Noble (2020), pp 6, 7, 11.

211 Jünemann (2018), p 61; Marian (2015-2016), p 53; Davidson (2019), p 802.

212 Jünemann (2018), p 61.

213 Block et al. (2020), p 2; Trotz (2019), p 455.

214 Dell'Erba (2018), p 1128; Basaran (2019), pp 773-777.

215 Similar considerations are related to national issues (Gurrea-Martinez and Remolina (2019), p 40).

216 Debler (2018), pp 268-270. See also Marian (2019), p 533.
} 


\subsection{Internationally Recommended Regulations in the Field of Crypto-Assets}

Instead of an international treaty, the development of non-binding model regulations at international level could be considered. Alternatively, global guidance on ICO matters could be developed. ${ }^{217}$

The above-mentioned international solutions could lead to world-wide uniformisation and standardisation of cryptocurrency issues. In that case, it would not be necessary to reach international consensus on these matters.

\section{New Legal Theory of Regulations in the Field of Initial Coin Offering}

\subsection{General Remarks}

It is doubtless that a new legal framework concerning crypto-assets should be created in the future. ${ }^{218}$ In most countries there are no special regulations,. ${ }^{219}$ This stems from the fact that crypto-asset trade is not common yet ${ }^{220}$ and is still in the beginning phase ${ }^{221}$ although it is starting to become mainstream. ${ }^{222}$ Furthermore, legislators are aware that the shape of the crypto-asset market is still evolving. ${ }^{223}$ Therefore, a 'wait-and-see' approach in the area of cryptocurrencies is still justified in contemporary legal systems. ${ }^{224}$

Nonetheless, it is necessary to discuss the shape of future legal regulations concerning crypto-assets. It is obvious that the entry into force of a new legal framework should be preceded by the creation of a new theory of crypto-financial law. ${ }^{225}$

\subsection{General Principles of a New Legal Framework in the Field of Crypto-assets}

Fundamental general principles of a future legal framework should be created before complex legal solutions concerning Initial Coin Offering are developed. ${ }^{226}$

\footnotetext{
217 Tiwari et al. (2020), p 435.

218 Briggs (2018), pp 426-427; Fong (2018), p 76; Hughes and Middlebrook (2015), p 498; Sherman (2018), pp 17-18; Davidson (2019), p 803.

219 Basaran (2019), pp 766, 777; O’Connor (2019), p 568; Kaal (2018), pp 47-48; Heideman (2019), p 137; Marian (2019), p 539.

220 Yano et al. (2019), p 109.

221 Amsden and Schweizer (2018), p 40.

222 Bratspies (2018), p 15.

223 Dell'Erba (2018), p 1116.

224 See Tjio and Hu (2020); Ally et al. (2015).

225 Cvetkova (2018), p 151. See also Dell'Erba (2018), p 1132; Davidson (2019), p 810.

226 Dell'Erba (2018), p 1132. See also Cvetkova (2018), p 151.
} 
First of all, a legal framework in the area of ICOs should be flexible ${ }^{227}$ in order to prevent future problems related to outdated legal regulations. This is crucial because the crypto-asset market and new financial technologies are still changing. ${ }^{228}$

Furthermore, new financial regulations should be protective of investors but should not discourage entrepreneurs. ${ }^{229}$ In view of the above, legislators should not limit the development of a modern financial market, but this should not lead to a 'Crypto Wild West'. ${ }^{230}$

New legal regulations in the area of Initial Coin Offering should be general in order to make it impossible to avoid them. ${ }^{231}$ It is also important to create clear principles related to jurisdiction in these matters. ${ }^{232}$

A new legal framework in the area of ICOs should be technologically neutral in order to be resistant to changes in financial technology and prevent avoidance of crypto regulations. $^{233}$

Finally, new financial regulations should focus on counteracting scams and fraud. ${ }^{234}$ However, they should not be too complex so as not to have a negative influence on the development of the crypto-asset market.

\subsection{Scope of the New Regulations}

New legal regulations in the field of ICOs should concern especially jurisdictional matters, ${ }^{235}$ issues of taxonomy, ${ }^{236}$ disclosure and reporting requirements, ${ }^{237}$ anti-money laundering principles, ${ }^{238}$ anti-fraud provisions, ${ }^{239}$ payment rules, ${ }^{240}$ liability insurance requirements, ${ }^{241}$ registration obligations, ${ }^{242}$ licence obligations, ${ }^{243}$ audit obligations, ${ }^{244}$

\footnotetext{
227 An et al. (2018), p 8; Link and Kunz (2019), p 18.

228 Steverding and Zureck (2020), p 36. See also Dell'Erba (2018), p 1116.

229 MacNiven (2018-2019), p 4; Hughes and Middlebrook (2015), pp 498-499.

${ }^{230}$ Lockaby (2018), p 366; Varriale (2013), p 17; Shulman (2020), pp 62, 75.

231 See Fong (2018), p 62.

232 Debler (2018), p 253; Fitts (2019), pp 928-929; Morton (2020), p 142; Alvarez (2018), p 56; Davidson (2019), p 790.

233 See Walker (2019), p 6; Essaghoolian (2019), p 330; Frick (2019), p 105.

234 Weber and Baisch (2019), pp 28-29.

235 Debler (2018), p 253; Fitts (2019), pp 928-929.

236 Lausen (2019), p 13. See also Dell'Erba (2020), p 223; Dell'Erba (2019), p 33; Rohr and Wright (2019), p 477.

237 Yano et al. (2019), p 109. See also Tiwari et al. (2020), p 438; Adhami and Giudici (2019), p 70; Howell et al. (2018-2019), p 14; MacNiven (2018-2019), p 7; Fong (2018), p 75; Preston (2017-2018), p 330.

238 Gurrea-Martinez and Remolina (2019), pp 35-36; Dell'Erba (2018), p 1121; Dell'Erba (2019), pp 28, 45 .

239 MacNiven (2018-2019), p 7; Briggs (2018), p 426.

240 van Beusekom (2019), p 25; Trotz (2019), p 440.

241 Trotz (2019), p 438.

242 See Tiwari et al. (2020), p 436; Higgins (2018), p 233; Essaghoolian (2019), p 339.

243 Arts. 13-16 of the Maltese Virtual Financial Assets Act 2018. https://legislation.mt/eli/cap/590/eng/ pdf. Accessed 14 July 2021.

244 See Dell'Erba (2019), pp 24-25.
} 
legal provisions concerning intermediaries, ${ }^{245}$ legal principles related to rating agencies, and secondary market issues. ${ }^{246}$

\subsection{Jurisdictional Issues}

Because of the fact that crypto-asset trade is borderless and virtual, ${ }^{247}$ developing effective principles of jurisdiction in the area of cryptocurrencies is extremely difficult. ${ }^{248}$ Jurisdictional problems are probably the main reason for the lack of regulations in the field of ICOs. ${ }^{249}$

Therefore, internationally binding principles of jurisdiction should be created. Such principles can be based on the notion of issuers' beneficial owners ${ }^{250}$ or the place of issuers' management. ${ }^{251}$ Regulations based on the place of registration may be ineffective because many entrepreneurs could decide to establish mailbox companies in blockchain paradises so as to avoid undesirable jurisdictions. ${ }^{252}$

It could also be considered to base the rules in question on the jurisdiction of the purchaser of the crypto-assets. Such jurisdiction could be valuable for anti-money laundering purposes.

\subsection{Normative Taxonomy of Cryptocurrencies}

Normative taxonomy of cryptocurrencies is not merely a theoretical issue. Payment tokens, utility tokens and investment tokens should be treated in different ways by regulators and legislators. For example, the Maltese Virtual Financial Assets Act is applicable only to financial tokens. ${ }^{253}$ Regulations concerning pure utility tokens should be focused on jurisdictional issues and anti-fraud rules, whereas regulations in the area of security tokens and payment tokens should be more complex and more developed. ${ }^{254}$ They should concern not only issues of jurisdiction $^{255}$ and manipulation ${ }^{256}$ but also matters related to registration of issuers, ${ }^{257}$

\footnotetext{
245 Tjio and Hu (2020); Weber and Baisch (2019), p 25.

246 See Tiwari et al. (2020), p 435; Crane (2018), p 812.

247 Marian (2019), p 554; Kaal (2018), p 42.

248 Maume and Fromberger (2019), p 563; Debler (2018), p 253; Fitts (2019), pp 928-929; Rohr and Wright (2019), p 485.

249 See Debler (2018), p 253.

250 See Marian (2019), p 542.

251 See Davidson (2019), p 823.

252 See Maume and Fromberger (2019), p 572; https://www.e-zigurat.com/innovation-school/blog/block chain-paradise/. Accessed 14 July 2021. See also Marian (2019), pp 529, 532, 541, 550, 551, 552, 553; Essaghoolian (2019), p 339.

253 Art. 3(1) of the Maltese Virtual Financial Assets Act 2018. https://legislation.mt/eli/cap/590/eng/pdf. Accessed 14 July 2021.

254 Tjio and $\mathrm{Hu}(2020)$.

255 Debler (2018), p 253; Fitts (2019), pp 928-929; Morton (2020), p 142; Alvarez (2018), p 56; Davidson (2019), p 790.

256 Briggs (2018), p 426.

257 See Tiwari et al. (2020), p 436; Preston (2017-2018), p 330.
} 
disclosure obligations, ${ }^{258}$ reporting standards $^{259}$ and secondary market principles. ${ }^{260}$

\subsection{Registration Obligations}

It is obvious that payment tokens and security tokens should be registered by their issuers. ${ }^{261}$ In many countries, crypto-assets are currently registered in registers which were created for traditional financial purposes. ${ }^{262}$ In some countries, there are special registers of crypto-assets for anti-money laundering purposes (e.g. in Australia) ${ }^{263}$ and general registers of crypto-assets (e.g. in Malta and Gibraltar). ${ }^{264}$ Central registers of crypto-assets, crypto-asset issuers and ICOs should be kept in all countries. ${ }^{265}$ The creation of an international register for crypto-asset purposes should also be considered.

Current methods of registration in the field of cryptocurrencies are based on standard solutions applicable to traditional financial instruments. ${ }^{266}$ However, crypto-assets have many digital features which can enable the entry into force of new methods of registration. For instance, the development of automatic methods of registration, which could be directly connected to smart contracts, could be considered. ${ }^{267}$ Such a solution could prove extremely effective in the case of ICOs. Hence, the obligation to register new tokens through smart contracts seems particularly innovative and ideally tailored to crypto-assets.

\subsection{Licence Obligation}

The quality of the professional activities of crypto-asset issuers, crypto-asset intermediaries, crypto-asset rating agencies and other institutions involved in cryptoasset trade could be ensured by the obligation to obtain special licences. ${ }^{268}$ Special

\footnotetext{
258 See Tiwari et al. (2020), p 438; Howell et al. (2018-2019), p 14; Preston (2017-2018), p 330.

259 Preston (2017-2018), p 330.

${ }^{260}$ See Trotz (2019), p 446; Briggs (2018), p 426; Gurrea-Martinez and Remolina (2019), pp 35-36.

${ }^{261}$ See Tiwari et al. (2020), p 435; O'Connor (2019), p 564.

${ }^{262}$ Crosser (2018), p 395.

${ }^{263}$ Part 6A of the Australian Anti-Money Laundering and Counter-Terrorism Financing Act 2006. https://www.legislation.gov.au/Details/C2019C00011. Accessed 14 July 2021.

${ }^{264}$ Alkadri (2018-2019), pp 85-86; Weber and Baisch (2019), p 18. See also arts. 3, 7 and 16 of the Maltese Virtual Financial Assets Act 2018. https://legislation.mt/eli/cap/590/eng/pdf. Accessed 14 July 2021. ${ }^{265}$ See Higgins (2018), p 233.

${ }^{266}$ See Crosser (2018), p 395. See also Part 6A, Division 3 of the Australian Anti-Money Laundering and Counter-Terrorism Financing Act 2006. https://www.legislation.gov.au/Details/C2019C00011. Accessed 14 July 2021.

267 See Robinson (2018), p 959; Olivier and Jaccard (2017), p 3.

${ }^{268}$ Crane (2018), p 813; Weber and Baisch (2019), pp 8, 13; Gurrea-Martinez and Remolina (2019), p 35. See also art. 13 of the Maltese Virtual Financial Assets Act 2018. https://legislation.mt/eli/cap/590/ eng/pdf. Accessed 14 July 2021.
} 
requirements ${ }^{269}$ should be included in regulations, imposing on crypto-asset issuers the obligation to obtain special licences. ${ }^{270}$

\subsection{Payment Rules}

Each ICO can turn out to be a scam. ${ }^{271}$ Therefore, several regulators from different countries decided to publish official warnings concerning ICO issues. ${ }^{272}$ However, such a solution is not effective and even naïve.

The most effective method of counteracting fraud committed by crypto-asset issuers seems to be special payment rules for ICO purposes. Some scholars postulate that payments for tokens should be made into a separate bank account ${ }^{273}$ which could be prepaid. ${ }^{274}$ This would be a good solution because it could protect crypto investors. Other researchers are of the opinion that tokens and money paid for cryptocurrencies issued should be held by third-party custodians. ${ }^{275}$ Such a model would lead to additional control over crypto issuers.

All the above-mentioned rules seem reasonable because they make it difficult for crypto-asset issuers to misappropriate investors' money or tokens. ${ }^{276}$

\subsection{Anti-money Laundering Regulations}

It is obvious that legislators should create special legal provisions to counteract money-laundering in the area of ICOs. ${ }^{277}$ Such regulations should be countermeasures against the anonymity and pseudonymity of investors and entrepreneurs. ${ }^{278}$

KYC (Know Your Customer) obligations should be imposed on issuers. ${ }^{279}$ Still, such obligations should not merely consist of a voluntary declaration of the investor. Investors should prove their identity through a bank transfer, digital signature or in another effective way.

\footnotetext{
269 See arts. 13-22 of the Maltese Virtual Financial Assets Act 2018. https://legislation.mt/eli/cap/ 590/eng/pdf. Accessed 14 July 2021. See also arts. 15(1) and 43 of the Proposal for a Regulation of the European Parliament and of the Council on Markets in Crypto-assets, and amending Directive (EU) 2019/1937 (COM/2020/593).

270 Weber and Baisch (2019), p 8; Gurrea-Martinez and Remolina (2019), p 35; Crane (2018), p 813. See also art. 13 of the Maltese Virtual Financial Assets Act 2018. https://legislation.mt/eli/cap/590/eng/ pdf. Accessed 14 July 2021.

271 An et al. (2018), p 2. See also MacNiven (2018-2019), p 11; Sherman (2018), p 17; Weber and Baisch (2019), pp 28-29.

272 Allen (2020), p 13.

273 van Beusekom (2019), p 25.

274 Hughes and Middlebrook (2015), p 534.

275 Trotz (2019), p 440.

276 See van Beusekom (2019), p 25; Tiwari et al. (2020), p 434.

277 Weber and Baisch (2019), p 23; Debler (2018), pp 252-254; Dell'Erba (2018), p 1121.

278 Gurrea-Martinez and Remolina (2019), p 37; Walker (2019), p 5; Hönig (2018), p 10; Marian (20152016), pp 57, 63; Morton (2020), p 138.

279 Gurrea-Martinez and Remolina (2019), p 35; Dell'Erba (2018), p 1121; Dell'Erba (2019), pp 28, 45; Adhami and Giudici (2019), p 71; Fong (2018), p 68; Debler (2018), p 254.
} 
Furthermore, countermeasures against the anonymity of investors should be supported by regulations on the international exchange of information in crypto-asset matters. ${ }^{280}$ For instance, it is suggested to create an International Information Sharing Agreement. ${ }^{281}$

\subsection{Disclosure Regulations}

\subsubsection{General Remarks}

In principle, no special rules concerning disclosure obligations in the case of ICOs are in force ${ }^{282}$ (except in the Maltese financial legal system ${ }^{283}$ ). It is obvious that such regulations could limit fraud. ${ }^{284}$ However, in some countries traditional financial regulations concerning prospectuses are applicable to ICOs. ${ }^{285}$

Instead of prospectuses, issuers of crypto-assets use several methods to communicate with potential investors. The most common method of disclosure of information on ICOs is the issuance of white papers, which are similar to prospectuses. ${ }^{286}$ Additionally, issuers use special forums, issuers' websites and social media as channels of communication with future purchasers of their coins and tokens. ${ }^{287}$ In Malta, white papers, issuers' websites and advertisements of ICOs must comply with binding legal regulations. ${ }^{288}$

There is no doubt that disclosure obligations should be imposed not only on issuers of crypto-assets but also on investors ${ }^{289}$ and that false disclosure of information should lead to civil, penal and administrative liability. ${ }^{290}$

\subsubsection{Disadvantages of White Papers}

Although disclosure of information on cryptocurrencies through white papers is the most common method of communication between issuers and future token holders, such documents have many major disadvantages. ${ }^{291}$

\footnotetext{
280 Debler (2018), pp 268-270. See also Marian (2019), p 533.

281 Debler (2018), p 268.

282 See An et al. (2018), p 8.

283 Arts. 3-5 of the Maltese Virtual Financial Assets Act 2018 https://legislation.mt/eli/cap/590/eng/pdf. Accessed 14 July 2021.

284 Brake (2020), p 193; Fong (2018), p 75.

285 See Crosser (2018), p 395; Miller et al. (2018), p 98; Arnold (2019), p 56; Weber and Baisch (2019), p 15.

286 See Tiwari et al. (2020), p 424; Iurina (2017), p 15; Marian (2019), p 539.

287 Danatzis (2019), p 32; van Beusekom (2019), p 17; Varmaz and Varmaz (2018), p 132; Meadows (2018), p 282.

288 Arts. 3-6 of the Maltese Virtual Financial Assets Act 2018. https://legislation.mt/eli/cap/590/eng/pdf. Accessed 14 July 2021.

289 Fong (2018), p 68.

290 Trotz (2019), pp 431, 450; Noto La Diega et al. (2019), p 7.

291 Steverding and Zureck (2020), p 21; Gurrea-Martinez and Remolina (2019), pp 18, 32; Boreiko and Risteski (2020), p 3; Liu and Wang (2019), p 129; Gurrea-Martinez and Remolina (2019), p 14; Dell'Erba (2019), p 25; Tiwari et al. (2020), p 435.
} 
First of all, there are no special regulations concerning mandatory information which should be in these white papers. ${ }^{292}$ This leads to informational asymmetry. ${ }^{293}$

Furthermore, the information in the white papers is not reviewed and audited by experts. ${ }^{294}$ For this reason, such information is frequently misleading. ${ }^{295}$

It should also be noted that there are no special liability rules which could apply to issues regarding white papers. In some countries, spreading misleading information through white papers can lead to liability under consumer protection law ${ }^{296}$ and civil law. ${ }^{297}$

Such misstatements should be prohibited under penalty of law. Legal principles related to civil liability could also be designed for the issuance of unreliable white papers, because there are often omissions and misinformation in those documents. ${ }^{298}$

Finally, current white papers are often difficult to understand. They should therefore be written in plain English. ${ }^{299}$

\subsubsection{Proposals for Mandatory Information to Be Disclosed in White Papers}

It is obvious that new legal provisions related to white papers should include a list of mandatory information to be disclosed, ${ }^{300}$ such as:

a. the issuers' and developers' identity; ${ }^{301}$

b. the beneficial owners of the issuer, ${ }^{302}$

c. the location of the issuer; ${ }^{303}$

d. the status and basic features of the issuer; 304

e. information on the issuer's activity; ${ }^{305}$

f. technical information on the tokens issued; ${ }^{306}$

\footnotetext{
${ }^{292}$ Steverding and Zureck (2020), p 21; Gurrea-Martinez and Remolina (2019), pp 18, 32; Meadows (2018), p 282.

293 Boreiko and Risteski (2020), p 3; Liu and Wang (2019), p 129.

${ }^{294}$ Gurrea-Martinez and Remolina (2019), p 14; Dell'Erba (2019), p 25; Tiwari et al. (2020), p 435.

295 Meadows (2018), p 282.

296 van Beusekom (2019), p 22.

297 van Beusekom (2019), p 2; Tiwari et al. (2020), p 432.

${ }^{298}$ Meadows (2018), p 282.

299 Trotz (2019), p 449.

300 Ibid., p 436.

301 Yano et al. (2019), pp 121-122; Trotz (2019), p 442.

${ }^{302}$ See Marian (2019), p 542.

303 Gurrea-Martinez and Remolina (2019), p 32.

${ }^{304}$ Yano et al. (2019), pp 121-122; art. 7(f) of the First Schedule to the Maltese Virtual Financial Assets Act. https://legislation.mt/eli/cap/590/eng/pdf. Accessed 14 July 2021.

${ }^{305}$ See Yano et al. (2019), pp 121-122; art. 7(j) of First Schedule to the Maltese Virtual Financial Assets Act. https://legislation.mt/eli/cap/590/eng/pdf. Accessed 14 July 2021.

${ }^{306}$ Gurrea-Martinez and Remolina (2019), p 13; Rohr and Wright (2019), p 465; art. 7(b) of the First Schedule to the Maltese Virtual Financial Assets Act. https://legislation.mt/eli/cap/590/eng/ pdf. Accessed 14 July 2021. See also arts. 5(1)(e) and 46(2)(e) of the Proposal for a Regulation of the European Parliament and of the Council on Markets in Crypto-assets, and amending Directive (EU) 2019/1937 (COM/2020/593).
} 
g. price of the tokens and methods of payment; $;^{307}$

h. number of tokens that are planned to be issued; ${ }^{308}$

i. rights of the investors; ${ }^{309}$

j. goals of the fundraising; 310

k. risks related to the ICO organised; ${ }^{311}$

1. investment strategy; ${ }^{312}$

m. detailed description of the financed project; ${ }^{313}$

n. usability of the financed project; ${ }^{314}$

o. information on potential investors and the distribution of tokens; ${ }^{315}$

p. predicted duration of the financed project; 316

q. predicted profits from the investment; ${ }^{317}$

r. auditor's opinion on the financed project; ${ }^{318}$

s. information on the complaint procedure, ${ }^{319}$

t. information on the financial guarantees; ${ }^{320}$

u. information on the reserve of assets, ${ }^{321}$

v. information on the risks related to the crypto-assets; ${ }^{322}$

307 van Beusekom (2019), p 17; art. 7(z) of the First Schedule to the Maltese Virtual Financial Assets Act. https://legislation.mt/eli/cap/590/eng/pdf. Accessed 14 July 2021.

308 Art. 7(p) of the First Schedule to the Maltese Virtual Financial Assets Act. https://legislation.mt/eli/ cap/590/eng/pdf. Accessed 14 July 2021.

309 See Gurrea-Martinez and Remolina (2019), p 13; Yano et al. (2019), pp 121-122; art. 17(1)(e) of the Proposal for a Regulation of the European Parliament and of the Council on Markets in Crypto-assets, and amending Directive (EU) 2019/1937 (COM/2020/593).

310 Howell et al. (2018-2019), p 17; art. 7(d) of the First Schedule to the Maltese Virtual Financial Assets Act. https://legislation.mt/eli/cap/590/eng/pdf. Accessed 14 July 2021.

311 Arts. 7(d) and art. 7 (ab) of the First Schedule to the Maltese Virtual Financial Assets Act. https:// legislation.mt/eli/cap/590/eng/pdf. Accessed 14 July 2021.

312 Dell'Erba (2018), p 1112.

313 Brake (2020), p 193; Meadows (2018), p 282; arts. 5(1)(b) and 46(2)(a) of the Proposal for a Regulation of the European Parliament and of the Council on Markets in Crypto-assets, and amending Directive (EU) 2019/1937 (COM/2020/593).

314 Brake (2020), p 193; Gurrea-Martinez and Remolina (2019), p 13; art. 7(c) of the First Schedule to the Maltese Virtual Financial Assets Act. https://legislation.mt/eli/cap/590/eng/pdf. Accessed 14 July 2021.

315 Arts. $7(\mathrm{k})$ and $7(\mathrm{~g})$ of the First Schedule to the Maltese Virtual Financial Assets Act. https://legis lation.mt/eli/cap/590/eng/pdf. Accessed 14 July 2021.

316 Brake (2020), p 193.

317 Dell'Erba (2018), p 1112; Gurrea-Martinez and Remolina (2019), p 13.

318 See Gurrea-Martinez and Remolina (2019), pp 13-14; art. 4(1)(ae) of the First Schedule to the Maltese Virtual Financial Assets Act. https://legislation.mt/eli/cap/590/eng/pdf. Accessed 14 July 2021.

319 Art. 17(1) $(\mathrm{g})$ of the Proposal for a Regulation of the European Parliament and of the Council on Markets in Crypto-assets, and amending Directive (EU) 2019/1937 (COM/2020/593).

${ }^{320}$ See art. 4(1)(x) of the First Schedule to the Maltese Virtual Financial Assets Act. https://legislation. mt/eli/cap/590/eng/pdf. Accessed 14 July 2021.

321 Art. 17(1)(b) of the Proposal for a Regulation of the European Parliament and of the Council on Markets in Crypto-assets, and amending Directive (EU) 2019/1937 (COM/2020/593).

322 Arts. 5(1)(f), 5(5) and 46(2)(e) of Proposal for a Regulation of the European Parliament and of the Council on Markets in Crypto-assets, and amending Directive (EU) 2019/1937 (COM/2020/593). 
w. information on issues regarding custody; ${ }^{323}$

x. information on the suitability of the ICO procedure for the financed project; ${ }^{324}$

y. information about tax issues significant for investors; ${ }^{325}$

z. the issuer's plans for the future. ${ }^{326}$

Furthermore, there are researchers who believe that Initial Business Plans should be attached to the white papers, ${ }^{327}$ which would be a good idea. It could even be considered to attach other documents, such as, for example, as stated in the MiCA proposal, summaries and warnings. ${ }^{328}$

\subsubsection{Reporting Obligations}

Disclosure obligations should also be fulfilled through temporary reporting, ${ }^{329}$ This means that issuers should be obliged to report amendments in the information included in the white papers, whereas owners of crypto-assets should be obliged to inform regulators of the purchase and disposal of their tokens. ${ }^{330}$

\subsection{Anti-manipulation Regulations}

Fraudulent ICOs are frequent. ${ }^{331}$ Some financial specialists even believe that all ICOs are scams, ${ }^{332}$ which seems exaggerated. However, counteracting manipulation and fraud in the field of ICOs is undoubtedly an extremely important task of legislators and regulators. ${ }^{333}$ In Malta, for instance, insider trading, illegal disclosure of information and abusive strategies related to crypto-assets are prohibited. ${ }^{334}$

\footnotetext{
323 Art. 17(1)(c) of the Proposal for a Regulation of the European Parliament and of the Council on Markets in Crypto-assets, and amending Directive (EU) 2019/1937 (COM/2020/593).

324 Art. 7(a) of the First Schedule to the Maltese Virtual Financial Assets Act. https://legislation.mt/eli/ cap/590/eng/pdf. Accessed 14 July 2021.

325 Art. 7(u) of First Schedule to the Maltese Virtual Financial Assets Act. https://legislation.mt/eli/cap/ 590/eng/pdf. Accessed 14 July 2021.

326 Yano et al. (2019), pp 121-122.

327 Adhami and Giudici (2019), p 68.

328 Arts. 17(2) and 5(7) of the Proposal for a Regulation of the European Parliament and of the Council on Markets in Crypto-assets, and amending Directive (EU) 2019/1937 (COM/2020/593).

329 Preston (2017-2018), p 330.

330 See Fong (2018), p 68.

331 MacNiven (2018-2019), p 11; Wilson (2019), p 368. See also Tiwari et al. (2020), p 430; Hönig (2018), p 24; Walker (2019), p 6; Block et al. (2020), p 7; Dell'Erba (2018), p 1112; Link and Kunz (2019), p 18; An et al. (2018), p 19; Dell'Erba (2020), p 182; Howden (2015), p 742; Essaghoolian (2019), p 297.

332 An et al. (2018), p 2.

333 Preston (2017-2018), p 319; Briggs (2018), p 426.

334 Arts. 33-37 of the Maltese Virtual Financial Assets Act 2018. https://legislation.mt/eli/cap/590/eng/ pdf. Accessed 14 July 2021.
} 
Primary market manipulation should especially be counteracted by auditors, whereas countermeasures against secondary market manipulation ${ }^{335}$ should impose obligations on crypto-exchanges and other trading platforms. ${ }^{336}$

\subsection{Audit Requirements, Rating Agencies and Lists of Trusted ICOs}

The quality of crypto-assets and ICOs should be evaluated in an organised and professional way. ${ }^{337}$ Such evaluation can be prepared by auditors ${ }^{338}$ or rating agencies. ${ }^{339}$ Eventually, regulators can draw up lists of trusted ICOs. ${ }^{340}$

There are those who believe that token holders should be protected through supervision and monitoring of ICOs by auditors and lawyers. ${ }^{341}$ They are quite right because ICOs should be supervised by reliable professionals. A serious problem is also the fact that the due diligence obligation does not exist in the case of ICOs. ${ }^{342}$

The role of rating agencies in these matters is currently played by listing platforms. ${ }^{343}$ Contrary to rating agencies, the quality of information provided by listing platforms is unstandardised. ${ }^{344}$ Legal regulations should be created as regards mandatory obligations to be fulfilled by such platforms.

It is important to add that France has an official white list of trusted ICOs. ${ }^{345} \mathrm{~A}$ similar register exists in Gibraltar. ${ }^{346}$ Such an idea could certainly be applied instead of audit requirements and regulations concerning listing platforms.

In view of the above, legal regulations concerning the evaluation of ICOs should be designed. Such regulations could concern listing platforms, audit obligations and official lists of trusted ICOs.

\subsection{Liability Insurance}

A significant problem related to ICOs is the lack of mandatory liability insurance. ${ }^{347}$ This obligation should be imposed on issuers of tokens, developers of ICOs and other institutions involved in ICOs. This legal solution would protect investors.

\footnotetext{
335 Meadows (2018), p 286.

336 Dell'Erba (2020), p 213; Trotz (2019), p 446. See also art. 37 of the Maltese Virtual Financial Assets Act 2018. https://legislation.mt/eli/cap/590/eng/pdf. Accessed 14 July 2021, and arts. 76-80 of the Proposal for a Regulation of the European Parliament and of the Council on Markets in Crypto-assets, and amending Directive (EU) 2019/1937 (COM/2020/593).

337 See Tiwari et al. (2020), p 435.

338 See Dell'Erba (2019); art. 50 of the Maltese Virtual Financial Assets Act 2018. https://legislation.mt/ eli/cap/590/eng/pdf. Accessed 14 July 2021.

339 See van Beusekom (2019), pp 7, 28.

340 Weber and Baisch (2019), p 16.

341 Gurrea-Martinez and Remolina (2019), p 32; Dell'Erba (2019), p 24.

342 Tiwari et al. (2020), p 434; Trotz (2019), p 436.

343 See van Beusekom (2019), pp 7, 28.

344 Ibid., p 32.

345 Weber and Baisch (2019), p 16.

346 Ibid., p 18.

347 Trotz (2019), p 438.
} 


\subsection{Regulations Concerning Crypto-asset Intermediaries}

Although the crypto-asset world is thought to be disintermediated, ${ }^{348}$ there are crypto-asset intermediaries such as crypto exchanges, ${ }^{349}$ clearing houses, ${ }^{350}$ wallet providers $^{351}$ and custody service providers. ${ }^{352}$

Issues related to the activities of such enterprises should be regulated because they can have an impact on the proper functioning of the crypto-asset market. ${ }^{353}$

It is obvious that all crypto-asset service providers should be neutral and independent of issuers. ${ }^{354}$ It seems extremely difficult to design standardised regulations concerning crypto-asset intermediaries because such intermediaries are greatly varied. ${ }^{355}$ The most important matters to be regulated in these legal provisions are jurisdictional issues regarding such enterprises.

\subsection{Secondary Market Regulations}

Crypto exchanges play a significant role in the post-ICO phase. ${ }^{356}$ Therefore, a proper and effective legal framework should be set up as regards the secondary crypto-asset market. 357

The most important legal task in such matters is the creation of jurisdictional rules related to crypto exchanges. This is obvious because conflicts of laws and avoidance of jurisdiction can become serious problems for the effectiveness of future regulations in the field of ICOs. So-called blockchain paradises, which are countries enabling the avoidance of jurisdiction in crypto-asset matters, should be counteracted. ${ }^{358}$

In the legislative process concerning secondary market regulations, lawmakers should also focus on anti-manipulation and anti-money laundering matters. ${ }^{359}$ It is especially important to create crypto-asset secondary market regulations based on current KYC (Know Your Customer) rules. ${ }^{360}$

\footnotetext{
348 Block et al. (2020), p 6; Lebersorger (2018), p 29; Varmaz and Varmaz (2018), p 130; Walker (2019), p 10; Dell'Erba (2020), p 177; Marian (2019), p 554.

349 Weber and Baisch (2019), p 25; Steverding and Zureck (2020), p 27.

350 Block et al. (2020), p 6; Marian (2015-2016), p 58; O’Connor (2019), p 560.

351 Weber and Baisch (2019), p 25; Hughes and Middlebrook (2015), p 496; Marian (2015-2016), p 58.

352 Trotz (2019), p 440; Hughes and Middlebrook (2015), p 497.

353 See Tjio and Hu (2020); Weber and Baisch (2019), p 25. See also arts. 57 and 62 of the Proposal for a Regulation of the European Parliament and of the Council on Markets in Crypto-assets, and amending Directive (EU) 2019/1937 (COM/2020/593).

354 See Trotz (2019), p 445.

355 Maume and Fromberger (2019), p 579.

356 Steverding and Zureck (2020), p 27.

357 Crane (2018), p 812.

358 https://www.e-zigurat.com/innovation-school/blog/blockchain-paradise/. Accessed 14 July 2021. See also Marian (2019), pp 529, 532, 550, 551, 552, 553.

359 See Trotz (2019), p 446; Briggs (2018), p 426; Brown (2019), p 154.

360 See Gurrea-Martinez and Remolina (2019), p 35.
} 
Finally, it is also necessary to impose registration, reporting and auditing requirements on crypto exchanges. Legal provisions on such issues should lead to improvement of the quality of crypto-asset services.

Such regulations would undoubtedly increase investors' security. They should be tailored for crypto-asset purposes but can be based on traditional financial legal solutions. This is extremely important because secondary market manipulation is a frequent occurrence. ${ }^{361}$

\section{Recommendations for Legislators}

First of all, legislators should emulate the regulations in force in other countries, which can thus lead to unofficial harmonisation of legal solutions regarding ICOs. This consideration is especially important in the field of jurisdictional matters. A similar strategy is recommended in the case of non-binding international and supranational legal documents in the area of cryptocurrencies (such as the MiCA proposal), which should also be adapted by national lawmakers.

Furthermore, national financial regulations concerning ICOs should be based on well-considered principles. ${ }^{362}$ Such principles could be:
a. technological neutrality; ${ }^{363}$
b. flexibility; 364
c. effectiveness; ${ }^{365}$ and
d. general nature of new solutions.

Legislators should also enact regulations enabling crypto-asset enterprises to automatically fulfil their registration, reporting and disclosure obligations through smart contracts. $^{366}$

It should be possible to apply general consumer law, contract law and financial law in the case of issues not regulated in new regulations. This means that new regulations should be supported by traditional legal solutions. However, legislators should mainly counteract the development of a so-called 'Crypto-Wild West' ${ }^{367}$ In this way, there should be no crypto-asset areas without regulations.

In the framework of these regulations, legislators should pay special attention to payment rules, ${ }^{368}$ anti-scam regulations, anti-manipulation principles ${ }^{369}$ and the

\footnotetext{
361 Meadows (2018), p 286.

${ }^{362}$ Dell'Erba (2018), p 1132; Cvetkova (2018), p 151.

363 Walker (2019), p 6; Essaghoolian (2019), p 330; Frick (2019), p 105.

364 An et al. (2018), p 8; Link and Kunz (2019), p 18.

${ }^{365}$ See Gurrea-Martinez and Remolina (2019), pp 31-32; Fong (2018), p 62.

${ }^{366}$ Preston (2017-2018), p 330; Robinson (2018), p 959.

367 See Lockaby (2018), p 366; Varriale (2013), p 17; Shulman (2020), p 62; Crosser (2018), p 381; Robinson (2018), p 960.

368 van Beusekom (2019), p 25; Trotz (2019), p 440.

${ }^{369}$ MacNiven (2018-2019), p 7; Briggs (2018), p 426.
} 
effectiveness of liability insurance requirements. ${ }^{370}$ Furthermore, crypto-investigation units should be set up $^{371}$ and it should be made difficult or impossible for wellestablished companies to use ICOs to avoid regulations concerning IPOs. ${ }^{372}$

In addition, obligations related to counteracting primary and secondary market manipulation should be imposed on crypto-asset intermediaries. A well-developed system of crypto licences should be set up as well. ${ }^{373}$

A well-organised system of support for investors and entrepreneurs should also be created. For instance, regulators could draw up lists of trusted crypto-asset issuers and crypto exchanges. ${ }^{374}$ Furthermore, national authorities should develop official platforms which could contribute to arriving at a professional and binding interpretation of the new legal regulations. ${ }^{375}$

\section{Recommendations for the European Union}

In view of the above considerations related to a European legal framework, a crypto-asset legal order compatible with the proposal for a MiCA Regulation would undoubtedly be extremely complicated, heterogenous and difficult to apply.

Therefore, general European regulations in the field of crypto-assets should be created. Such legal provisions should be well thought out so as not to be discriminative or favourable in comparison with general regulations in the field of financial instruments.

Crypto-asset regulations should definitely be harmonised. ${ }^{376}$ There are also justified opinions that the MiCA Regulation and financial European provisions should be coordinated. ${ }^{377}$

It is also obvious that current proposals for regulations in the field of cryptoassets are temporary. Hence, it is necessary to design comprehensive legal regulations regarding cryptocurrencies in the next phase of harmonisation of these matters.

\footnotetext{
370 Trotz (2019), p 438.

371 Such units exist at national levels (Mokhtarian and Lindgren (2018), pp 138, 150; Vrazel (2019), p 559; Marian (2019), pp 563-564).

372 Higgins (2018), p 221; Essaghoolian (2019), p 294.

373 See Noto La Diega et al. (2019), p 7; Crane (2018), p 813; Weber and Baisch (2019), pp 8, 13; Gurrea-Martinez and Remolina (2019), p 35; art. 13 of the Maltese Virtual Financial Assets Act 2018. https://legislation.mt/eli/cap/590/eng/pdf. Accessed 14 July 2021.

374 Such list exist, for example, in France (Weber and Baisch (2019), p 16).

375 Such platforms exist in Australia (see the Australian ASIC's sheet entitled: Innovation hub: practical support and informal assistance. https://asic.gov.au/for-business/innovation-hub/. Accessed 14 July 2021).

376 See Mathis (2020), p 11.

377 Zetzsche et al. (2020), p 24.
} 


\section{Recommendations for the International Community}

An international system of standardised regulations in the field of crypto-assets needs to be developed. Such a system could be based not only on a multilateral treaty but also on bilateral agreements. ${ }^{378}$ Furthermore, a new international organisation whose tasks would concern crypto-asset matters, could be created. ${ }^{379}$ Model regulations in the area of crypto-assets could be developed under the auspices of such an organisation.

There is no doubt that international uniform principles of jurisdiction should be enacted in an international treaty on crypto-asset matters, ${ }^{380}$ with respect to the fact that jurisdictional rules should be the same in all countries as jurisdictional conflicts in the area of ICOs are to be avoided.

Furthermore, the international community must counteract blockchain paradises and crypto-mailbox companies. ${ }^{381}$ In view of the above, issues related to the exchange of information in crypto-asset matters should be regulated in bilateral agreements. ${ }^{382}$ It would also be a good idea to conclude model bilateral conventions on the exchange of information in these matters. ${ }^{383}$

\section{Conclusions}

Although most countries have adopted a 'wait and see' approach in the area of Initial Coin Offerings, ${ }^{384}$ new regulations should be designed to ensure a proper functioning of the token market. ${ }^{385}$

New regulations should not be 'ad hoc', ${ }^{386}$ which means that a legal theory of cryptocurrencies and a legal theory of Initial Coin Offering should be created before legal acts concerning these matters enter into force. ${ }^{387}$ Furthermore, new crypto regulations in Member States should be based on the solutions included in the proposal for a MiCA Regulation. This is regardless of whether the MiCA will enter into force or not. It stems from the fact that the relevant legal provisions should be uniform.

First and foremost, new crypto-asset regulations should be general and technologically neutral. ${ }^{388}$ Such a solution should make it difficult to avoid new legal

\footnotetext{
378 Debler (2018), pp 268-270.

379 See Basaran (2019), p 773; Howden (2015), pp 745-746.

380 See Gurrea-Martinez and Remolina (2019), p 40; Morton (2020), p 1142.

381 See Maume and Fromberger (2019), p 572; https://www.e-zigurat.com/innovation-school/blog/block chain-paradise/. Accessed 14 July 2021. See also Marian (2019), pp 529, 532, 550, 551, 552, 553.

382 Debler (2018), pp 268-270.

383 Ibid.

384 See Ally et al. (2015); Tjio and Hu (2020).

385 Gamble (2017), p 348.

386 Dell'Erba (2020), p 179.

387 See Cvetkova (2018), p 151; Dell'Erba (2018), p 1132.

388 See Walker (2019), p 6; Essaghoolian (2019), p 330; Frick (2019), p 105.
} 
provisions. Technologically neutral regulations should also be resistant to future changes in financial and cryptographic technologies.

Regardless of technological neutrality, disclosure and reporting obligations should be fulfilled automatically through smart contracts. ${ }^{389}$ A similar solution could be applicable to registration. 390

Furthermore, it is necessary to elaborate a taxonomy of tokens and Initial Coin Offering. This is crucial because Initial Coin Offerings of payment tokens, investment tokens and utility tokens should be subject to different legal regulations.

Regulations on payment and security tokens should definitely act as countermeasures against fraud, whereas in the case of financial regulations concerning utility tokens, legislators and legal theoreticians should focus on general principles of consumer protection.

The most complex regulations should concern investment tokens. Such legal provisions should be based on current financial regulations but must differ from them because of the fully virtual nature of crypto-assets.

The main legal problem of cryptocurrencies, which should be solved immediately, is the jurisdictional issue. Principles of jurisdiction should be discussed in an international forum under the auspices of an international organisation competent in such matters.

However, none of the existing international organisations is involved in the process of designing future crypto-asset regulations. ${ }^{391}$ Therefore, such regulations should be created at national level. Until international regulations enter into force, national principles of jurisdiction in the field of ICOs should be based on the location of the beneficial owners of the issuers or the location of the purchasers of crypto-assets.

It is recommended that the new legal framework in the area of investment tokens should be based on a detailed division of ICO phases.

Regulations concerning the pre-ICO phase could concern especially audit requirements and disclosure obligations related to white papers and the process of obtaining licences. ${ }^{392}$

Regulations applicable to issues regarding primary market trade should be developed. New regulations should be applied to payment, ${ }^{393}$ registration, ${ }^{394}$ anti-money laundering (especially Know Your Customer obligations) ${ }^{395}$ and mandatory liability insurance requirements. ${ }^{396}$

\footnotetext{
389 See Olivier and Jaccard (2017), p 3; Crosser (2018), p 386.

390 Ibid.

391 Basaran (2019), p 773.

392 See Steverding and Zureck (2020), p 19; Adhami and Giudici (2019), p 63; Varmaz and Varmaz (2018), p 132; Crane (2018), p 813; Weber and Baisch (2019), pp 8, 13; Gurrea-Martinez and Remolina (2019), p 35.

393 See van Beusekom (2019), p 25; Trotz (2019), p 440.

394 See Tiwari et al. (2020), p 436; Higgins (2018), p 233; Essaghoolian (2019), p 339.

395 Dell'Erba (2019), pp 28, 45; Dell'Erba (2018), p 1121; Adhami and Giudici (2019), p 71; Fong (2018), p 68; Debler (2018), p 254; Gurrea-Martinez and Remolina (2019), pp 35-36.

396 Trotz (2019), p 438.
} 
Regulations applicable to the post-ICO phase should focus on reporting obligations and the proper functioning of crypto exchanges, other crypto-asset intermediaries and listing platforms. ${ }^{397}$ Furthermore, obligations related to counteracting secondary market manipulation should be imposed on crypto-asset intermediaries. ${ }^{398}$

There is no doubt that new financial regulations in the area of ICOs should be well conceived and resistant to technological changes. Because of the fact that the crypto-asset trade is global, new regulations should be internationally uniform.

Open Access This article is licensed under a Creative Commons Attribution 4.0 International License, which permits use, sharing, adaptation, distribution and reproduction in any medium or format, as long as you give appropriate credit to the original author(s) and the source, provide a link to the Creative Commons licence, and indicate if changes were made. The images or other third party material in this article are included in the article's Creative Commons licence, unless indicated otherwise in a credit line to the material. If material is not included in the article's Creative Commons licence and your intended use is not permitted by statutory regulation or exceeds the permitted use, you will need to obtain permission directly from the copyright holder. To view a copy of this licence, visit http://creativecommons.org/licen ses/by/4.0/.

\section{References}

Adhami S, Giudici G (2019) Initial coin offerings: tokens as innovative financial assets. In: Hacioğlu Ü (ed) Blockchain economics and financial market innovation. Springer, New York, pp 61-81

Alkadri S (2018-2019) Defining and regulating cryptocurrencies: fake investment money or legitimate medium of exchange? Duke L Tech Rev 17:71-98

Allen F (2020) Initial coin offerings, corporate finance and financial regulation. Digital currency economics and policy workshop E-book, pp 1-18. https://papers.ssrn.com/sol3/papers.cfm?abstract_id= 3664684. Accessed 14 July 2021

Ally M, Gardiner M, Lane M (2015) The potential impact of digital currencies on the Australian economy. https://aisel.aisnet.org/acis2015/136/. Accessed 14 July 2021

Alvarez M (2018) A comparative analysis of cryptocurrency regulation in the United States, Nigeria, and China: the potential influence of illicit activities on regulatory evolution. ILSA J Intl Comp L 25(1):33-56

Amsden R, Schweizer D (2018) Are blockchain crowdsales the new 'gold rush'? Success determinants of initial coin offerings. https://papers.ssrn.com/sol3/papers.cfm?abstract_id=3163849. Accessed 14 July 2021

An J, Hou W, Liu X (2018) Initial Coin Offerings: investor protection and disclosure. Working paper. https://scholar.google.com/scholar?hl=pl\&as_sdt=0\%2C5\&q=Initial+Coin+Offerings\%3A+Inves tor+Protection+and+Disclosure \&btnG $=$. Accessed 14 July 2021

Arnold T (2019) Empirische und rechtliche Analyse von Initial Coin Offerings in Deutschland - Erfolgsfaktoren eines alternativen Finanzierungsweges für Startups. Universität Ulm. https://oparu.uni-ulm. de/xmlui/handle/123456789/12255. Accessed 14 July 2021

Basaran HR (2019) Businesspersons, governments, and international law. Louisiana L Rev 79(3):749-780

Block J, Groh A, Hornuf L, Vanacker T, Vismara S (2020) The entrepreneurial finance markets of the future: a comparison of crowdfunding and Initial Coin Offerings. Small Bus Econ 57:865-882. https://doi.org/10.1007/s11187-020-00330-2

\footnotetext{
397 See Steverding and Zureck (2020), pp 19, 27; Adhami and Giudici (2019), p 63; Dell'Erba (2020), p 213; Trotz (2019), p 446.

398 See Trotz (2019), p 446; Dell'Erba (2020), p 213.
} 
Boreiko D, Risteski D (2020) Serial and large investors in Initial Coin Offerings. Small Bus Econ 57:1053-1071. https://doi.org/10.1007/s11187-020-00338-8. Accessed 14 July 2021

Brake E (2020) For love or for profit? - Crafting a suitable securities framework for initial coin offerings. Maine L Rev 72(1):155-196

Bratspies R (2018) Cryptocurrency and the myth of the trustless transaction. Mich Tech L Rev 25(1):1-58

Breier M, Hongler P, Winzap M (2018) Taxing tokens - A Swiss perspective on the taxation of Initial Coin Offerings and blockchain-based tokens. Tax Notes Int 89(12):1159-1168

Briggs K (2018) Taming the Wild West: how the SEC can legitimize Initial Coin Offerings (ICOs), protect consumers from bad actors, and encourage blockchain development. Bus Entrep Tax L Rev 2:424-450

Brown M (2019) Cryptocurrency and financial regulation: the SEC's rejection of bitcoin-based ETP. N C Bank Inst 23:139-158

Chohan UW (2017) Initial Coin Offerings (ICOs): risks, regulation, and accountability. https://doi.org/10. 2139/ssrn.3080098. Accessed 14 July 2021

Chudinovskikh M, Sevryugin V (2019) Cryptocurrency regulation in the BRICS countries and the Eurasian Economic Union. BRICS Law J 6(1):63-81. https://doi.org/10.21684/ 2412-2343-2019-6-1-63-81

Clements R (2018) Assessing the evolution of cryptocurrency: demand factors, latent value, and regulatory developments. Mich Bus Entrep L Rev 8(1):73-100

Crane E (2018) Regulation without deflation: cryptocurrency and its insider trading conundrum. J Marshall L Rev 51(4):797-818

Crosser N (2018) Initial Coin Offerings as investment contracts: are blockchain utility tokens securities? Univ Kansas L Rev 67(1):379-422

Cvetkova I (2018) Cryptocurrencies legal regulations. BRICS Law J 5(2):128-153. https://doi.org/10. 21684/2412-2343-2018-5-2-128-153

Danatzis S (2019) Analyse de deux méthodes de financement: Initial Public Offering (IPO) vs Initial Coin Offering (ICO). Louvain School of Management, Université catholique de Louvain. http://hdl. handle.net/2078.1/thesis:20581. Accessed 14 July 2021

Davidson E (2019) A middle-ground for cryptocurrency regulation: using Delaware's incentive-driven private-ordering model. J Corp Law 44(4):789-826

Debler J (2018) Foreign Initial Coin Offering issuers beware: the Securities and Exchange Commission is watching. Cornell Int L J 51(1):245-272

Dell'Erba M (2018) Initial Coin Offerings: the response of regulatory authorities. NYU J L Bus 14:1107-1136

Dell'erba M (2019) Stablecoins in cryptoeconomics. From initial coin offerings to central bank digital currencies. NYU J Legis Pub Poly 22(1):1-44

Dell'Erba M (2020) From inactivity to full enforcement: the implementation of the 'do no harm' approach in initial coin offerings. Mich Tech L Rev 26(2):175-228

Essaghoolian N (2019) Initial Coin Offerings: emerging technology's fundraising innovation. UCLA L Rev 66(1):294-344

Ferrari V (2020) The regulation of crypto-assets in the EU - investment and payment tokens under the radar. Maastricht J Eur Compar Law (MJECL) 27(3):325-342

Fitts W (2019) Initial coin offerings: getting rid of the venture capitalist. Tenn J Bus L 20:927-932

Fong A (2018) Blocking the chain: regulating the initial coin offering. De Lege Ferenda 1:62-76

Frick TA (2019) Virtual and cryptocurrencies - regulatory and anti-money laundering approaches in the European Union and in Switzerland. ERA Forum 20:99-112. https://doi.org/10.1007/s12027-01900561-1.Accessed14July2021

Gamble C (2017) The legality and regulatory challenges of decentralised crypto-currency: a Western perspective. Int'1 Trade Bus L Rev 20:346-361

Gurrea-Martinez A, Remolina N (2019) The law and finance of initial coin offerings. SMU Centre for AI \& Data Governance Research Paper No 2019/06. https://papers.ssrn.com/sol3/papers.cfm?abstract_ $\mathrm{id}=3182261$. Accessed 14 July 2021

Heideman A (2019) Can 'IMFCOIN' be Scaruffi's moneta immaginaria? Marq Intell Prop L Rev 23(2):137-152

Higgins M (2018) Munchee Inc: a turning point for the cryptocurrency industry. N C L Rev 97(1):220-241 
Hönig M (2018) Initial Coin Offering - Studie zu Kryptowährungen und der Blockchain-Technologie. https://www.frankfurt-university.de/fileadmin/standard/Hochschule/Fachbereich_3/Kontakt/Profe ssor_inn_en/Hoenig/20180502_Bitcoin_Studie_fra_uas_Hoenig_V1.0.pdf. Accessed 14 July 2021

Howden E (2015) The crypto-currency conundrum: regulating an uncertain future. Emory Int L Rev 29(4):741-798

Howell S, Niesner M, Yermack D (2018-2019) Initial coin offerings: financing growth with cryptocurrency token sales. European Corporate Governance Institute (ECGI) - Finance Working Paper No. 564/2018. https://doi.org/10.2139/ssrn.3201259. Accessed 14 July 2021

Hughes S, Middlebrook S (2015) Advancing a framework for regulating cryptocurrency payments intermediaries. Yale J on Reg 32(2):495-560

Iurina A (2017) Initial Coin Offering in Gibraltar - Case study: Calidumcoin. https://www.theseus.fi/bitst ream/handle/10024/138654/Iurina_Alina.pdf?sequence=1\&isAllowed=y. Accessed 14 July 2021

Jünemann M (2018) German regulation of cryptocurrencies and ICOs. NYSBA Int Law Pract 31(1):61-64

Kaal W (2018) Initial coin offerings: the top 25 jurisdictions and their comparative regulatory responses. Stanford J Blockchain L Pol'y 1:41-63

Kapsis I (2020) A truly future-oriented legal framework for fintech in the EU. Eur Bus Law Rev 31(3):475-514. http://hdl.handle.net/10454/17638. Accessed 14 July 2021

Knecht M (2017-2018) Der Blockchain Hype. IMVS Fokus Report 8:5-9

Lausen J (2019) Regulating initial coin offerings? A taxonomy of crypto-assets. Paper presented at the 27th European Conference on Information Systems (ECIS2019), Stockholm-Uppsala, Sweden, 8-14 June 2019. https://aisel.aisnet.org/ecis2019_rp/26/. Accessed 14 July 2021

Lebersorger M (2018) Bewertung von Initial Coin Offerings. Masterarbeit. Johannes Kepler Universität Linz. https://epub.jku.at/obvulihs/content/titleinfo/2874682. Accessed 14 July 2021

Link B, Kunz H (2019) Initial Coin Offering - Chancen und Risiken eines kryptowährungsbasierten Finanzierungsmodells. Karlsruher Hochschulschriften für Wirtschaftsingenieurwesen und International Management 1(2019):1-22

Liu C, Wang H (2019) Crypto tokens and token offerings: an introduction. In: Goutte S, Guesmi K, Saadi S (ed) Cryptofinance and mechanisms of exchange. https://doi.org/10.1007/978-3-030-30738-7_8. Accessed 14 July 2021

Lockaby CD (2018) The SEC rides into town: defining an ICO securities safe harbor in the cryptocurrency 'Wild West'. Georgia L Rev 53(1):335-366

MacNiven B (2018-2019) Initial Coin Offerings: striking a balance between protecting investors and fostering growth. Rutgers Bus L J 14:1-22

Marian O (2015-2016) A conceptual framework for the regulation of cryptocurrencies. The University of Chicago L Rev Dialogue 82:53-68

Marian O (2019) Blockchain havens and the need for their internationally-coordinated regulation. N C J L Tech 20(4):529-568

Mathis B (2020) Which European regulation for security tokens? https://ssrn.com/abstract=3537446. Accessed 14 July 2021

Maume P, Fromberger M (2019) Regulations of initial coin offerings: reconciling U.S. and E.U. securities laws. Chicago J Int L 19(2):548-585

Meadows M (2018) The evolution of crowdfunding: reconciling regulation crowdfunding with initial coin offerings. Loyola Consumer L Rev 30:272-295

Miller L, Reutlinger M, Kaiser PJA (2018) Entwicklungen in der Regulierung von virtuellen Währungen in der Schweiz und der Europäischen Union. Zeitschrift für Europarecht (EuZ) 20(3):80-102

Mokhtarian E, Lindgren A (2018) Rise of the crypto hedge fund: operational issues and best practices for an emergent investment industry. Stanford J L Bus Fin 23(1):112-158

Moran J (2018) The impact of regulatory measures imposed on initial coins offerings in the United States market economy. Catholic Univ J L Tech 26(2):213-258

Morton D (2020) The future of cryptocurrency: an unregulated instrument in an increasingly regulated global economy. Loyola U Chi Int L Rev 16(1):129-143

Noble E (2020) Crypto-assets-Overcoming impediments to scaling: A view from the EU. https://ssrn. com/abstract $=3748343$. Accessed 14 July 2021

Noto La Diega G, Allsopp R, Onitiu D, Rasiah S, Thanaraj A (2019) Digital currencies: an analysis of its present regulation in the UK: a collaborative essay by NINSO, the Northumbria Internet \& Society Research Interest Group. https://www.researchgate.net/publication/334222026_Digital_Currencies_ 
An_Analysis_of_Its_Present_Regulation_in_the_UK_A_Collaborative_Essay_by_NINSO_the_ Northumbria_Internet_Society_Research_Interest_Group. Accessed 14 July 2021

O'Connor M (2019) Overreaching its mandate: considering the SEC's authority to regulate cryptocurrency exchanges. Drexel L Rev 11(2):539-596

Olivier G, Jaccard B (2017) Smart contracts and the role of law. Jusletter IT 23:1-25

Preston J (2017-2018) Initial coin offerings: innovation, democratization and the SEC. Duke Law Technol Rev 16:318-332

Robinson RA II (2018) The new digital Wild West: regulating the explosion of initial coin offerings. Tennessee L Rev 85(4):897-960

Rohr J, Wright A (2019) Blockchain-based token sales, initial coin offerings, and the democratization of public capital markets. Hastings L J 70:463-524

Rucker T (2020) The new frontier of campaign finance regulations: cryptocurrency. U Louisville L Rev 58(2):381-406

Sherman NJ (2018) A behavioral economics approach to regulating initial coin offerings. Georgetown L J Online 107:17-35

Shulman J (2020) ICOs, cryptos, blockchain, oh my!: a primer on ICOs. Rutgers Computer \& Tech L J 46(1):53-94

Stacher D (2018) Regulation of initial coin offering (ICO). An international comparison with focus on Switzerland. Universität Basel. https://wwz.unibas.ch/fileadmin/user_upload/wwz/00_Professuren/ Berentsen_Wirtschaftstheorie/Lecture_Material/Master_s_Thesis/Completed_Master_s_Theses/ Master_Thesis_David_Stacher.pdf. Accessed 14 July 2021

Steverding F, Zureck A (2020) Initial coin offerings in Europe - the current legal framework and its consequences for investors and issuers. https://ssrn.com/abstract=3536691. Accessed 14 July 2021

Tiwari M, Gepp A, Kumar K (2020) The future of raising finance - a new opportunity to commit fraud: a review of initial coin offering (ICOs) scams. Crime Law Soc Chang 73(2):417-441. https://doi.org/ 10.1007/s10611-019-09873-2

Tjio H, Hu Y (2020) Collective investment: land, crypto and coin schemes: regulatory 'property.' Eur Bus Org Law Rev (EBOR) 21:171-198

Trotz E (2019) Tangled up in blue: adapting securities laws to initial coin offerings. N IL U L Rev 39:428-455

van Beusekom AV (2019). Zivilrechtliche Aspekte von KMU-Finanzierung durch Utility Token Offerings: Rechtsprobleme und Perspektiven für Erwerber von Utility Token. https://doi.org/10.2139/ ssrn. 3515237

Varmaz A, Varmaz N (2018) Eine empirische Analyse von Initial Coin Offerings (ICO). Vierteljahrshefte zur Wirtschaftsforschung 87(3):129-150

Varriale G (2013) Bitcoin: regulating the Wild West: the proliferation of the cryptocurrency is financial authorities' next test. Int'1 Fin L Rev 32(8):17

Vrazel N (2019) Betting it all on the flip of a coin: regulating cryptocurrency initial coin offerings and protecting investors. South Texas L Rev 60(3):527-564

Walker GA (2019) Initial coin offerings - technology and the rule of law. ROLACC. https://doi.org/10. 5339/rolacc. 2019.7

Weber R, Baisch R (2019) Internationale Entwicklungen in der Crypto-Asset-Regulierung (ICO/Token). Jusletter Weblaw AG. https://jusletter.weblaw.ch/juslissues/2019/968/entwicklungen-in-der_b0bcc de3ed.html_ONCE\&login=false. Accessed 14 July 2021

Wilson C (2019) Cryptocurrencies: the future of finance? In: Yu FT, Kwan DS (eds) Contemporary issues in international political economy. Palgrave Macmillan, pp 359-394. https://www.researchga te.net/publication/333298389_Cryptocurrencies_The_Future_of_Finance. Accessed 14 July 2021

Yano M, Dai C, Masuda K, Kishimoto Y (2019) Blockchain business and its regulation. https://econp apers.repec.org/paper/etipolidp/19030.htm. Accessed 14 July 2021

Zetzsche D, Annunziata F, Arner DW, Buckley RP (2020) The markets in crypto-assets regulation (MiCA) and the EU digital finance strategy. EBI Working Paper Series No. 2020/77. https://ssrn. com/abstract $=3725395$. Accessed 14 July 2021

Publisher's Note Springer Nature remains neutral with regard to jurisdictional claims in published maps and institutional affiliations.

Paweł Szwajdler Assistant professor at Kazimierz Wielki University in Bydgoszcz, Ph.D. in law, attorney-at-law and licensed stockbroker. 